Prepared in cooperation with the Quinault Indian Nation

\title{
Water Temperature in the Lower Quinault River, Olympic Peninsula, Washington, June 2016-August 2017
}

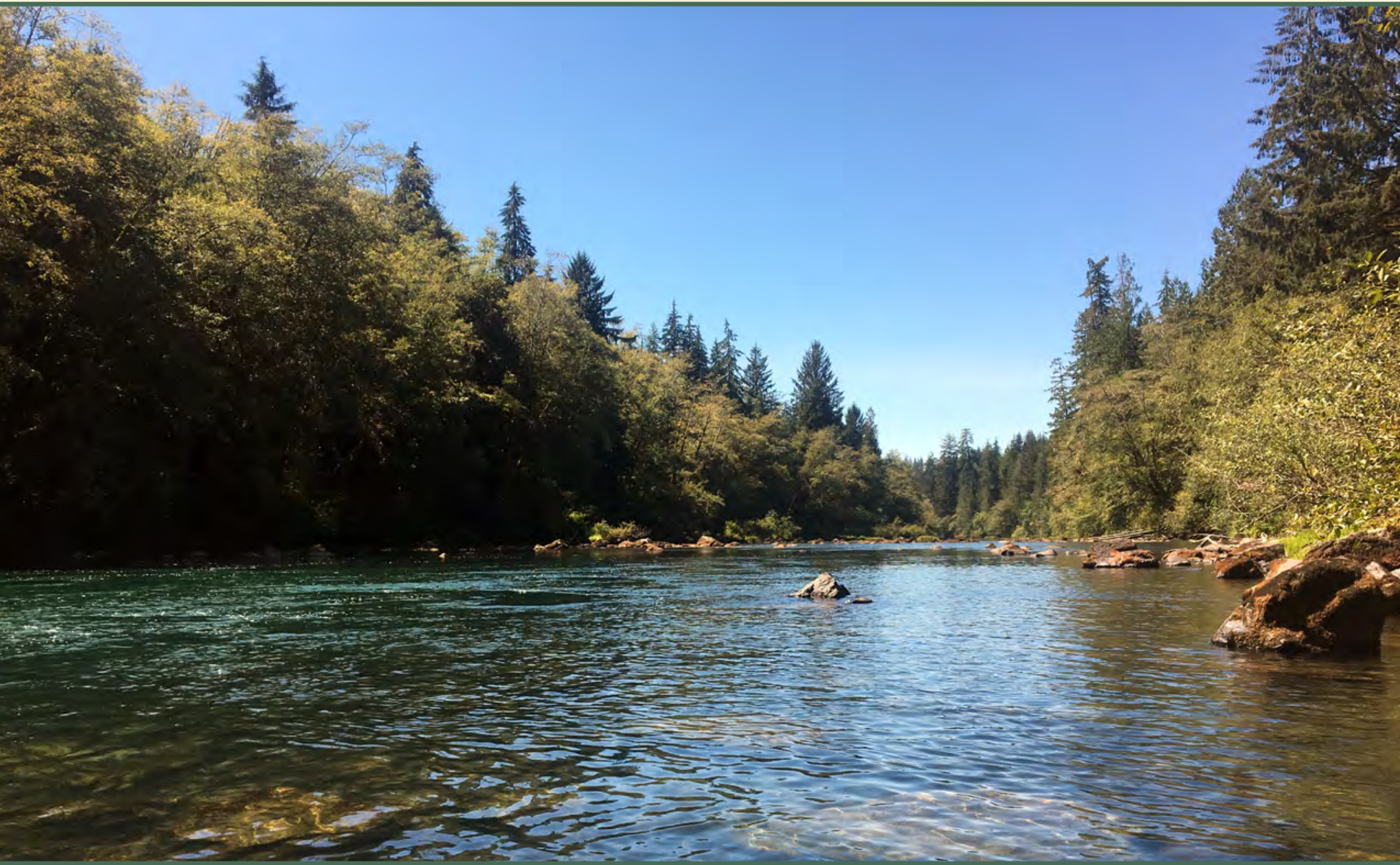

Open-File Report 2018-1129

U.S. Department of the Interior U.S. Geological Survey 
Cover: Quinault River looking downstream near the Amanda Park Bridge and U.S. Geological Survey (USGS) streamgage - Quinault River at Quinault Lake (12039500). Photograph by Elyse J. Wulfkuhle, USGS, August 17, 2016. 


\section{Water Temperature in the Lower Quinault River, Olympic Peninsula, Washington, June 2016-August 2017}

By Kristin L. Jaeger, Christopher A. Curran, Elyse J. Wulfkuhle, and Chad C. Opatz

Prepared in cooperation with the Quinault Indian Nation

Open-File Report 2018-1129 


\section{U.S. Department of the Interior \\ RYAN K. ZINKE, Secretary}

\section{U.S. Geological Survey \\ James F. Reilly II, Director}

U.S. Geological Survey, Reston, Virginia: 2018

For more information on the USGS-the Federal source for science about the Earth, its natural and living resources, natural hazards, and the environment-visit https://www.usgs.gov/ or call 1-888-ASK-USGS (1-888-275-8747).

For an overview of USGS information products, including maps, imagery, and publications, visit https:/store.usgs.gov.

Any use of trade, firm, or product names is for descriptive purposes only and does not imply endorsement by the U.S. Government.

Although this information product, for the most part, is in the public domain, it also may contain copyrighted materials as noted in the text. Permission to reproduce copyrighted items must be secured from the copyright owner.

Suggested citation:

Jaeger, K.L., Curran, C.A., Wulfkuhle, E.J., and Opatz, C.O., 2018, Water temperature in the lower Quinault River, Olympic Peninsula, Washington, June 2016-August 2017: U.S. Geological Survey Open-File Report 2018-1129, 24 p., https://doi.org/10.3133/ofr20181129.

ISSN 2331-1258 (online) 


\section{Contents}

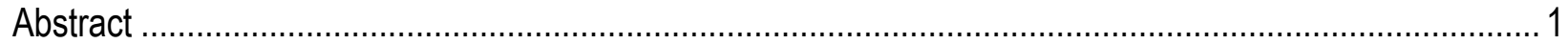

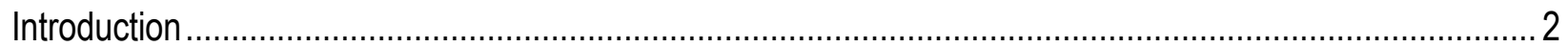

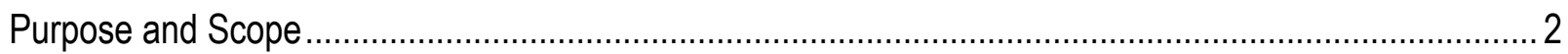

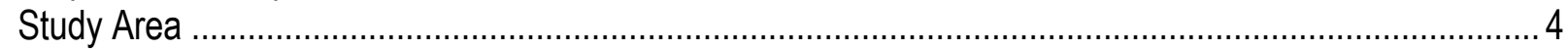

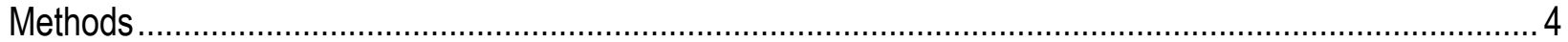

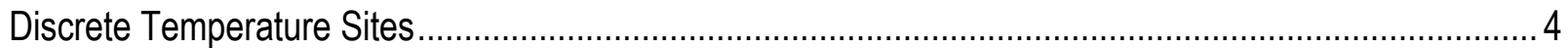

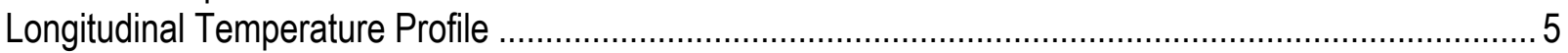

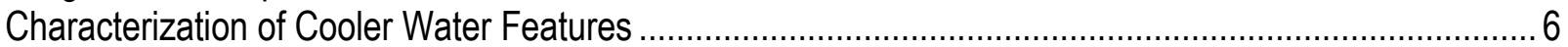

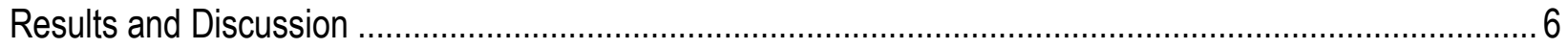

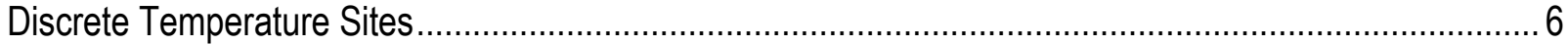

Coarse-Scale Downstream Trends in Water Temperature …....................................................... 14

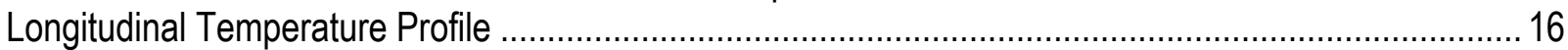

Characterization of Reach-Scale Cooler Water Features................................................................. 20

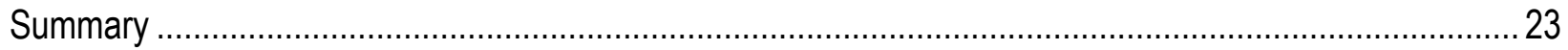

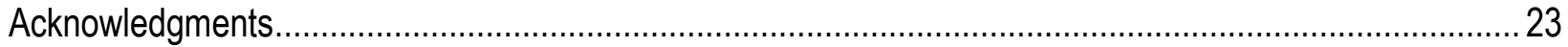

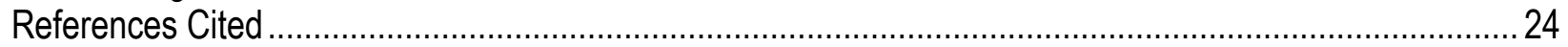

\section{Figures}

Figure 1. Map showing location of 10 temperature monitoring sites, including the USGS streamgage Quinault River at Quinault Lake (12039500) and 9 discrete sites, and extent of longitudinal temperature profile survey, lower Quinault River, Olympic Peninsula, Washington.................................... 3

Figure 2. Boxplots of differences between primary and secondary temperature sensors at the nine discrete temperature monitoring sites, lower Quinault River, Olympic National Park, Washington ........ 8

Figure 3. Graph showing discharge and daily mean water temperature at USGS streamgage

Quinault River at Quinault Lake (12039500), Olympic Peninsula, Washington, June 2016-August 2017 .... 9

Figure 4. Graphs showing daily mean water temperature at monitoring sites T10, T9, and T8, lower

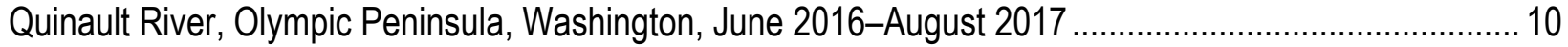

Figure 5. Graphs showing daily mean water temperature at monitoring sites T7, T6, and T5, lower Quinault River, Olympic Peninsula, Washington, June 2016-August 2017.

Figure 6. Graphs showing daily mean water temperature at monitoring sites T4, T3, and T2, lower Quinault River, Olympic Peninsula, Washington, June 2016-August 2017

Figure 7. Boxplots of daily minimum temperatures at USGS streamgage Quinault River at Quinault Lake (12039500) and the six sites with complete data over the 15-month study period, lower Quinault River, Olympic Peninsula, Washington, June 2016-August 2017.

Figure 8. Orthoimage showing location of near-streambed temperatures during the longitudinal profile survey and 11 potential cool water features and 1 warm water feature along the lower Quinault River (river kilometer 13-50), Olympic Peninsula, Washington, August 9-11, 2016

Figure 9. Graph showing water temperature at the USGS streamgage Quinault River at Quinault Lake (12039500) and an Onset ${ }^{\circledR}$ Hobo temperature sensor deployed at the downstream extent of the longitudinal profile to represent magnitude of the diurnal cycle, lower Quinault River, Olympic Peninsula, Washington, August 9-12, 2016

Figure 10. Graphs showing surface and near-streambed water temperatures, and water depth during the longitudinal profile survey along the lower Quinault River (approximately river kilometers 13-49), Olympic Peninsula, Washington, August 9-12, 2016. 


\section{Tables}

Table 1. List of temperature monitoring sites, lower Quinault River, Olympic Peninsula, Washington .......... 7

Table 2. Differences in degrees Celsius between the primary and secondary temperatures sensors at nine discrete temperature monitoring sites, lower Quinault River, Olympic Peninsula, Washington............. 7

Table 3. Summary of daily temperature values for USGS streamgage Quinault River at Quinault Lake (12039500) and temperature monitoring sites, lower Quinault River, Olympic Peninsula, Washington....

Table 4. Depth and near-streambed temperature at cross sections along potential cool water features and one potential warm water feature (WWF) in the lower Quinault River, Olympic Peninsula, Washington, June 2016-August 2017

\section{Conversion Factors}

U.S. customary units to International System of Units

\begin{tabular}{|c|c|c|}
\hline Multiply & By & To obtain \\
\hline \multicolumn{3}{|c|}{ Flow rate } \\
\hline cubic foot per second $\left(\mathrm{ft}^{3} / \mathrm{s}\right)$ & 0.02832 & cubic meter per second $\left(\mathrm{m}^{3} / \mathrm{s}\right)$ \\
\hline \multicolumn{3}{|c|}{ International System of Units to U.S. customary units } \\
\hline Multiply & By & To obtain \\
\hline \multicolumn{3}{|c|}{ Length } \\
\hline meter $(\mathrm{m})$ & 3.281 & foot $(\mathrm{ft})$ \\
\hline kilometer $(\mathrm{km})$ & 0.6214 & mile (mi) \\
\hline kilometer $(\mathrm{km})$ & 0.5400 & mile, nautical (nmi) \\
\hline meter $(\mathrm{m})$ & 1.094 & yard (yd) \\
\hline \multicolumn{3}{|c|}{ Area } \\
\hline square kilometer $\left(\mathrm{km}^{2}\right)$ & 247.1 & acre \\
\hline square kilometer $\left(\mathrm{km}^{2}\right)$ & 0.3861 & square mile $\left(\mathrm{mi}^{2}\right)$ \\
\hline
\end{tabular}

\section{Flow rate}

\begin{tabular}{lll}
\hline cubic meter per second $\left(\mathrm{m}^{3} / \mathrm{s}\right)$ & 70.07 & acre-foot per day $($ acre-ft $/ \mathrm{d})$ \\
cubic meter per second $\left(\mathrm{m}^{3} / \mathrm{s}\right)$ & 35.31 & cubic foot per second $\left(\mathrm{ft}^{3} / \mathrm{s}\right)$ \\
\hline
\end{tabular}

Temperature in degrees Celsius $\left({ }^{\circ} \mathrm{C}\right)$ may be converted to degrees Fahrenheit $\left({ }^{\circ} \mathrm{F}\right)$ as ${ }^{\circ} \mathrm{F}=\left(1.8 \times{ }^{\circ} \mathrm{C}\right)+32$.

\section{Datum}

Horizontal coordinate information is referenced to the North American Datum of 1983 (NAD 83).

\section{Abbreviations}

$\begin{array}{llll}\text { CWF } & \text { cooler water features } & \text { NWIS } & \text { National Water Information System } \\ \text { ESA } & \text { Endangered Species Act } & \text { RK } & \text { river kilometer } \\ \text { GPS } & \text { Global Positioning System } & \text { USGS } & \text { U.S. Geological Survey } \\ \text { NIST } & \text { National Institute of Standards and Technology } & \text { WWF } & \text { warmer water features }\end{array}$




\title{
Water Temperature in the Lower Quinault River, Olympic Peninsula, Washington, June 2016-August 2017
}

\author{
By Kristin L. Jaeger, ${ }^{1}$ Christopher A. Curran, ${ }^{1}$ Elyse J. Wulfkuhle, ${ }^{2}$ and Chad C. Opatz ${ }^{1}$
}

\begin{abstract}
The availability of cold-water refugia during summertime river-water temperature maximums is important for cold-water fish species including Endangered Species Act listed salmonids since water temperature influences metabolism, growth, and phenology. The U.S. Geological Survey monitored water temperature at 10 sites approximately evenly-spaced along the lower Quinault River on the Olympic Peninsula, Washington, from June 2016 to August 2017 to assess thermal conditions in the lower river. During this 15-month period, there was a near-continuous, 15-minute record at 7 of the sites; complications with thermistors at 3 of the 10 sites limited the temperature dataset to include only summer 2016. In addition, near-streambed and water-surface temperatures were measured along the lower river during a longitudinal survey from August 9 to 12, 2016, during summer baseflow conditions to potentially identify cold or cooler water regions. Measured August water temperatures were warmer than model-predicted August temperatures for the period, 1993-2011. Summertime (July-September) daily minimum temperatures exceeded established salmon habitat threshold temperatures of $16^{\circ} \mathrm{C}$ (core summer season) and $17.5^{\circ} \mathrm{C}$ (spawning, rearing, and migration periods) for 122 and 65 days, respectively, on average at all monitoring sites with a complete 15-month record that included two summer baseflow periods. Summertime water temperatures at those sites were generally cooler in the downstream direction along the lower Quinault River but became warmer in the downstream direction during the rest of the year, suggesting the river was influenced by diffuse discharge of groundwater with a relatively constant annual temperature. The August longitudinal temperature survey did not detect cold-water refugia (features more than $3{ }^{\circ} \mathrm{C}$ cooler than ambient stream water), although it did identify 11 cooler water features (CWF) approximately $100-800 \mathrm{~m}$ in length that were $0.1^{\circ} \mathrm{C}$ cooler than adjacent upstream or downstream water. The CWFs appeared to correspond to local geomorphic conditions. In August 2017, 10 of the 11 CWFs were field surveyed, and 5 appeared to be influenced by shading from solar radiation by riparian vegetation or steep cliff banks. In addition, field observations suggest that finer scale (that is, less than $10 \mathrm{~m}$ ) CWFs, specifically individual side pools associated with large, in-channel wood, increased in frequency in the downstream direction along the lower Quinault River. However, this study did not quantify the density or water temperatures associated with these finescale features that may serve as cool- or cold-water pockets or patches.
\end{abstract}

\footnotetext{
${ }^{1}$ U.S. Geological Survey.

${ }^{2}$ Quinault Indian Tribe.
} 


\section{Introduction}

Water temperature is an important water-quality parameter for cold-water fish species including Endangered Species Act (ESA)-listed salmonids since water temperature influences metabolism, growth, and phenology. Cold-water refugia in streams and rivers are particularly critical habitat for salmonid species and other aquatic biota during summer low-flow periods when stream temperatures are at a maximum. Cold-water refugia, where water temperatures are at least $3{ }^{\circ} \mathrm{C}$ colder than ambient streamflow temperatures (Ebersole and others, 2003), or cooler water features (CWF) where water temperatures are relatively cooler than adjacent reaches (Fullerton and others, 2017), often are associated with areas of groundwater or hyporheic upwelling or in-channel features such as pools, large wood, or confluences with cold-water tributaries. Summertime stream temperatures, in addition to changes in baseflows, are likely to be limiting factors for many Washington State salmon populations in coming decades (Mantua and others, 2010). Stream temperature data are limited for the Olympic Peninsula in the northwestern region of the State, but historical (1970-99) and projected (2020s-80s) maximum stream temperatures range from favorable to stressful for salmon (Mantua and others, 2010; Fullerton and others, 2017).

The Quinault River flows from the Olympic Mountains within the Olympic National Park to the Pacific Ocean, draining a total area of $1,134 \mathrm{~km}^{2}$ (fig. 1). Lake Quinault, a natural moraine-dammed lake, separates the lower and upper sections of the river at approximately river kilometer (RK) 51.6 and 56.6 (O'Connor and others, 2003). The release of warmed lake surface water likely increases stream water temperatures in the lower Quinault River relative to the upper river (Mellina and others, 2002; Olden and Naiman, 2010). Therefore, cold-water refugia may become increasingly more important in the lower Quinault River as lake and river water temperature increase because of warmer air temperatures and lower summer streamflows relative to historical conditions as a result of decreased future snowpack and glacier meltwater associated with climate change (Mote and Salathé, 2010).

\section{Purpose and Scope}

This report presents stream water temperature data for the lower Quinault River and characterizes the longitudinal distribution of temperature with a focus on identifying cold-water refugia or CWFs. Specifically, this report presents water temperature data from 10 discrete sites that are approximately evenly spaced along the lower river to potentially identify larger scale (tens of kilometers) downstream trends in water temperature. Additionally, this report presents the longitudinal stream temperature profile for the lower Quinault River, extending approximately $1.6 \mathrm{~km}$ downstream from the outlet of Lake Quinault at RK 51.6 to RK 4, to help in identifying cold or CWFs in the river. For this study, cold-water refugia are defined as water temperature at least $3{ }^{\circ} \mathrm{C}$ colder than ambient streamflow temperatures (Ebersole and others, 2003), and CWFs are defined as short (tens to hundreds of meters) sections of river that are shorter and at least $0.1{ }^{\circ} \mathrm{C}$ cooler than adjacent upstream and downstream river segments. 


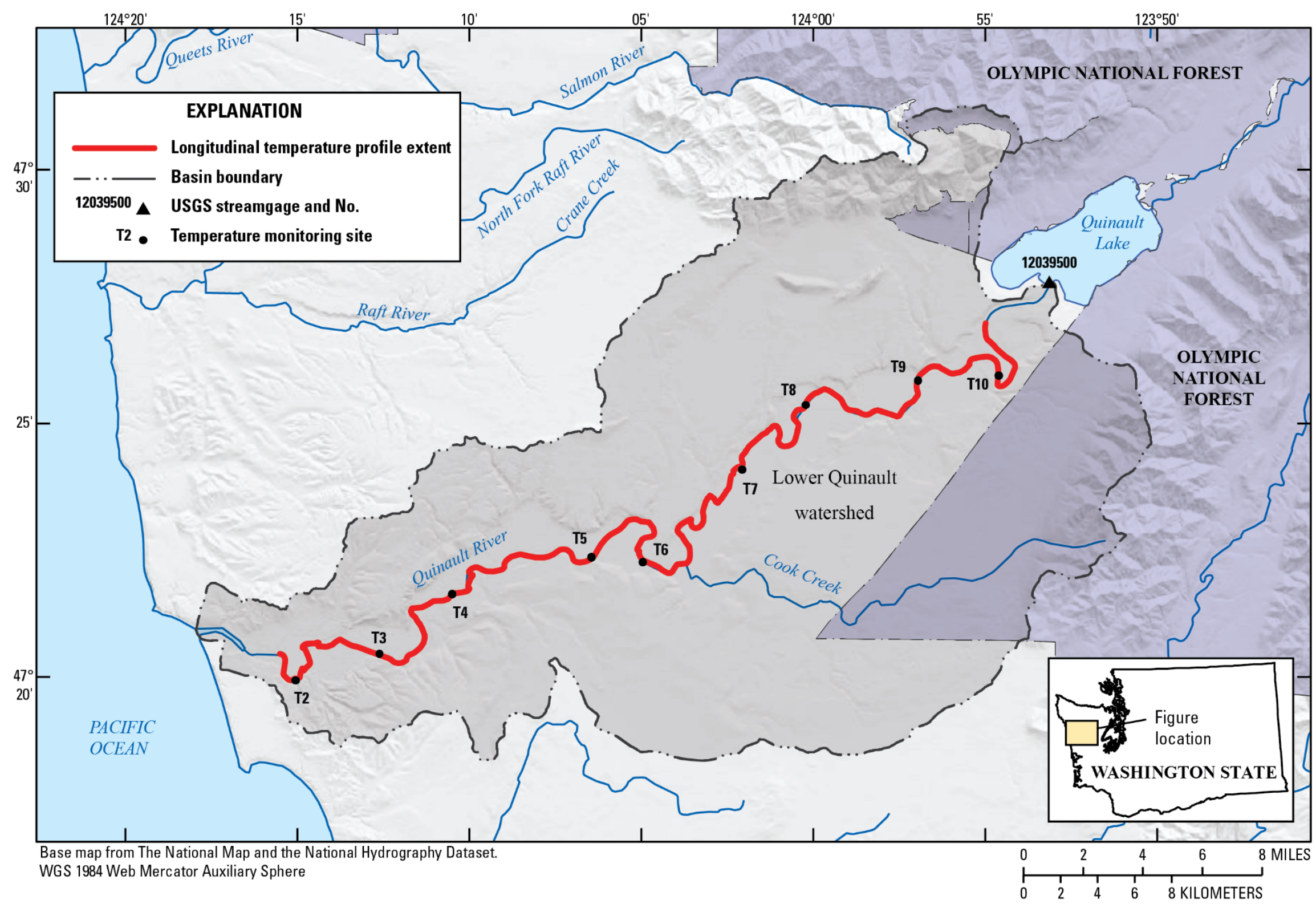

Figure 1. Map showing location of 10 temperature monitoring sites, including the USGS streamgage Quinault River at Quinault Lake (12039500) and 9 discrete sites, and extent of longitudinal temperature profile survey, lower Quinault River, Olympic Peninsula, Washington. 


\section{Study Area}

The river flows through a mostly forested floodplain, which has been subject to timber harvest activities since the late 1920s (O'Connor and others, 2003). The lower Quinault River was included in an analysis of historical channel and floodplain dynamics by O'Connor and others (2003), which details historical changes in (1) channel planform (1980s-1994), and (2) lateral channel migration and floodplain turnover rates (1895-1997). For the observed study period, the lower Quinault River was shown to have the narrowest floodplain, narrowest active channel, lowest channel migration rate, and the simplest geomorphic planform compared to the more dynamic upper Quinault and neighboring Queets Rivers, which is attributed to the moderating influence of Lake Quinault on flood hydrology and sediment transport on the lower river.

\section{Methods}

\section{Discrete Temperature Sites}

Near-streambed temperature was measured at nine sites along the lower Quinault River from June 23, 2016, to August 10, 2017 (fig. 1). All temperature data were collected, processed, reviewed, and approved according to established USGS policy for continuous water-quality data (Wagner and others, 2006). Water temperature was measured at 15-minute intervals using an Onset ${ }^{\circledR}$ Hobo TidbiT v2 (manufacturer reported $\pm 0.2^{\circ} \mathrm{C}$ accuracy). A second temperature sensor, Onset Hobo Pro v2 (manufacturer reported $\pm 0.2^{\circ} \mathrm{C}$ accuracy), provided by the Quinault Indian Nation, was installed within $3 \mathrm{~m}$ of the primary sensor at each site to provide redundancy in the event of primary sensor loss or failure. The temperature sensors were housed in open-ended galvanized steel pipe leashed with cable to a Duckbill ${ }^{\circledR}$ anchor that was driven into the riverbed following methods described by L. Adelfio (Oregon State University, written commun., June 2016). All temperature sensors were verified prior to deployment in a 4-point procedure that exceeded the range of temperatures recorded in the lower Quinault River by a National Institute of Standards and Technology (NIST) certified thermistor. Recovered temperature sensors were verified again in a 2-point procedure that exceeded the range of temperatures recorded in the lower Quinault River following sensor retrieval in August 2017. Because of the remoteness of the field sites, quarterly field calibration checks were not feasible. Temperature data were retrieved in August 2016 and August 2017. A cross section profile of near-streambed temperature was done during the June 2016 sensor installation at each of the nine sites using a NISTcertified thermistor to confirm that the temperature point measurement was representative of the cross section. A second cross section profile was done again in August 2017 at sites where sensors were retrieved.

Water temperature also was measured at a tenth site using a WaterLOG ${ }^{\circledR} \mathrm{H}-377$ at USGS streamgage lower Quinault River at Lake Quinault (12039500) at the upstream extent of the study area where the lake surface water discharges into the lower Quinault River. Water temperature data at the USGS streamgage was recorded at 15-minute intervals and transmitted hourly by satellite from the streamgage to the USGS Automated Data Processing System. Water temperature data at the USGS streamgage and at the nine discrete sites are available through NWIS, USGS Water-Quality Data for Washington, as "Historical Observations" (U.S. Geological Survey, 2018). River kilometers (RK) referred to in this report were measured from the 2014 stream channel. 


\section{Longitudinal Temperature Profile}

A longitudinal profile of the near-streambed temperature, water-surface temperature, and channel depth were measured on the lower Quinault River following methods outlined by Vaccaro and Maloy (2006). The survey was done over 4 days from August 9 to 12, 2016, by towing temperature sensors behind a raft traveling downstream at the ambient velocity along the channel thalweg. Nearstreambed water temperature and depth were measured at a 1 -second interval using a Solinst ${ }^{\circledR}$ Levelogger $3001 \mathrm{LT}$ F15/M5 sensor that was towed by a raft and dragged along the streambed. The potential for disturbed bed sediments to affect temperature is not expected given that the sensor was enclosed in PVC and the sensor was continuously moving in the downstream direction. Water surface temperature was measured at a 10-second interval using an Onset Hobo Pro v2 towed by the same raft but floating at the water surface. The upstream and downstream extents of the surveyed reach were bounded by additional temperature sensors during the longitudinal survey period to evaluate diurnal trends in stream temperature warming. The WaterLOG H-377 temperature sensor installed at USGS streamgage 12039500 at an approximate depth of $0.5 \mathrm{~m}$ served as the bounded upstream extent. An Onset Hobo Pro v2 was installed in the approximate middle of the water column approximately $0.5 \mathrm{~km}$ downstream of the downstream extent of the survey reach. All temperature sensors used for the longitudinal profile survey were verified by a NIST-certified thermistor in a 5-point procedure that exceeded the range of temperatures recorded in the lower Quinault River. Location was concurrently measured, using a Garmin ${ }^{\circledR}$ 60C sx Global Positioning System (GPS, approximately 0.3-m resolution, approximately 5-m accuracy) stored on the raft, at 5-second intervals on August 9 and 10, and at 15second intervals on August 11 for the upstream $37 \mathrm{~km}$ of the profile survey.

Temperature, depth, and location values represent either adjusted or interpolated values. A linear relation between the Solinst Levelogger and the NIST-certified thermistor was identified during the 5-point verification procedure because of the Solinst Levelogger measuring slightly lower temperatures compared to the NIST-certified thermistor. The linear adjustment was applied to the Solinst Levelogger measurements (eq. 1) based on a four-point regression $\left(\mathrm{R}^{2}=1\right.$, p-value $\left.<0.0001\right)$ that did not include temperatures less than $10^{\circ} \mathrm{C}$ because the lowest temperature measured for the longitudinal profile was substantially higher $\left(17.9^{\circ} \mathrm{C}\right)$. The linear adjustment equation is:

$$
y=0.9827 x+0.7304
$$

where

$x \quad$ is the Solinst Levelogger temperature measurement, and

$y \quad$ is the adjusted temperature.

This resulted in a temperature adjustment of approximately $+0.4{ }^{\circ} \mathrm{C}$ for the measured range of temperatures $\left(17.9-21.7^{\circ} \mathrm{C}\right)$. Additionally, depth measured by the Solinst Levelogger was adjusted with a $1.258-\mathrm{m}$ offset, identified by immersing the sensor under independently measured water depths in a laboratory.

The GPS location and concurrent water-surface temperature for each near-streambed temperature and depth measurement were identified by matching the same time stamps across the Solinst Levelogger, the Onset Hobo sensor, and the GPS device. Because water-surface temperature and GPS location were collected at time intervals greater than the 1-second interval of the nearstreambed temperature and depth measurements, missing values were linearly interpolated based on the known water-surface temperature or GPS coordinates that bracket the missing time periods for these measurements. GPS location was not collected for the lower $9 \mathrm{~km}$ (after August 12, 2016, at 9:15:01 a.m., Pacific Daylight Time) of the longitudinal profile survey because of data storage limitations of the GPS device. However, approximate reference location was matched to select time stamp locations based on survey field notes. The longitudinal profile for depth, and water surface and near-streambed temperatures are available in Jaeger and others (2018). 


\section{Characterization of Cooler Water Features}

The CWFs were identified from the longitudinal temperature survey data and were further evaluated in the field in August 2017. Identification of CWF was based on visual inspection of the data for portions of the profile with either a decrease (typically $0.1^{\circ} \mathrm{C}$ ) or constant temperature value over a given distance that typically extended for tens of meters. The locations of the CWF were then evaluated using Google Earth $^{\circledR}$ imagery for additional information on local conditions that may be associated with the CWF, for example, a tributary confluence.

Field evaluation of the CWF included characterizing water temperature conditions within the CWF and field verifying local conditions that may be a cause for the CWF. A temperature cross section was measured both upstream and downstream of the identified CWF and one to five additional cross sections were measured along the length of each CWF. Cross sections included a depth to the riverbed and near-streambed temperature measurement at five evenly spaced locations across the wetted width using an instant-read NIST-certified temperature sensor. Observations, including presence of shading, large wood, and water depth, were noted where appropriate as potential indicators of controls on CWFs. Surveys occurred over a several days in August 2017 during a range of weather conditions from warm and sunny to cool and rainy. Cross sections along a shallow, unshaded section of the river were done to serve as a potential reference for an expected warmer water feature (WWF). Cross sections of water depth and near-bed water temperatures for CWFs and the single WWF are available in Jaeger and others (2018).

\section{Results and Discussion}

\section{Discrete Temperature Sites}

The temperature record at 6 of the 9 discrete sites and the 10th site at the USGS streamgage extends from June 24, 2016, to August 23, 2017 (table 1; U.S. Geological Survey, 2018). The temperature record at the remaining three sites (T3, T5, and T7) includes part of summer 2016 (June 24 to August 10, 2016; U.S. Geological Survey, 2018). Data were retrieved from all sites in August 2016 except for one individual failure in the redundant sensor at T3. Sensors were retrieved at six of the nine sites in August 2017; sensors were not found at T3, T5, and T7 (table 1). Comparison of the primary and secondary sensors indicated that mean temperature difference between the two sensors was about $0.2{ }^{\circ} \mathrm{C}$ or less at each of the nine sites, which is within range of the sensor accuracy (table 2). Temperature differences were greater at T6 (fig. 2) because of the primary sensor being installed in a pool and the secondary sensor installed adjacent to the pool since options were limited for sensor deployment in this section of the river. The temperature record from the secondary sensor adjacent to the pool was chosen for analysis at T6. The secondary sensor at T2 was retrieved from burial under a tree root in August 2017 and the temperature record from this sensor was used for analysis; the primary sensor was not recovered at this site. 
Table 1. List of temperature monitoring sites, lower Quinault River, Olympic Peninsula, Washington.

[Monitor sites are listed in downstream direction and site locations are shown in figure 1]

\begin{tabular}{|c|c|c|c|c|c|}
\hline Site name & $\begin{array}{c}\text { Streamgage } \\
\text { or site No. }\end{array}$ & Latitude & Longitude & $\begin{array}{l}\text { Temperature } \\
\text { sensor type }\end{array}$ & Period of record \\
\hline USGS streamgage & 12039500 & 47.45778 & -123.8881 & $\begin{array}{c}\text { WaterLOG }^{\circledR} \\
\text { H-377 }\end{array}$ & June 24, 2016-August 23, 2017 \\
\hline $\mathrm{T} 10$ & 12039503 & 47.432399 & -123.910396 & Tidbit & June 24, 2016-August 23, 2017 \\
\hline T9 & 12039504 & 47.430867 & -123.949381 & Hobo & June 24, 2016-August 23, 2017 \\
\hline $\mathrm{T} 8$ & 12039507 & 47.422602 & -124.003967 & Tidbit & June 24, 2016-August 23, 2017 \\
\hline $\mathrm{T} 7$ & 12039509 & 47.401431 & -124.03467 & Tidbit & June 24, 2016-August 10, 2016 \\
\hline T6 & 12039511 & 47.371117 & -124.082879 & Hobo & June 24, 2016-August 23, 2017 \\
\hline T5 & 12039514 & 47.372716 & -124.107716 & Tidbit & June 24, 2016-August 10, 2016 \\
\hline $\mathrm{T} 4$ & 12039516 & 47.360647 & -124.175239 & Tidbit & June 24, 2016-August 21, 2017 \\
\hline $\mathrm{T} 3$ & 12039517 & 47.3409 & -124.2105 & Tidbit & June 24, 2016-August 10, 2016 \\
\hline $\mathrm{T} 2$ & 12039518 & 47.332152 & -124.251079 & Hobo & June 24, 2016-August 23, 2017 \\
\hline
\end{tabular}

Table 2. Differences in degrees Celsius between the primary and secondary temperatures sensors at temperature monitoring sites, lower Quinault River, Olympic Peninsula, Washington.

[Monitor sites are listed in downstream direction and site locations are shown in figure 1. NA at T3 is a result of failed secondary sensor]

\begin{tabular}{|c|c|c|c|c|}
\hline Site name & Minimum & Median & Mean & Maximum \\
\hline T10 & -1.09 & 0.20 & 0.20 & 0.29 \\
\hline T9 & 0.00 & 0.17 & 0.17 & 0.34 \\
\hline $\mathrm{T} 8$ & 0.02 & 0.21 & 0.21 & 0.41 \\
\hline $\mathrm{T} 7$ & 0.09 & 0.14 & 0.14 & 0.33 \\
\hline T6 & -2.79 & 0.20 & 0.14 & 2.16 \\
\hline T5 & 0.12 & 0.17 & 0.18 & 0.33 \\
\hline $\mathrm{T} 4$ & 0.02 & 0.14 & 0.15 & 0.24 \\
\hline T3 & NA & NA & NA & NA \\
\hline $\mathrm{T} 2$ & -0.21 & 0.14 & 0.14 & 0.27 \\
\hline
\end{tabular}




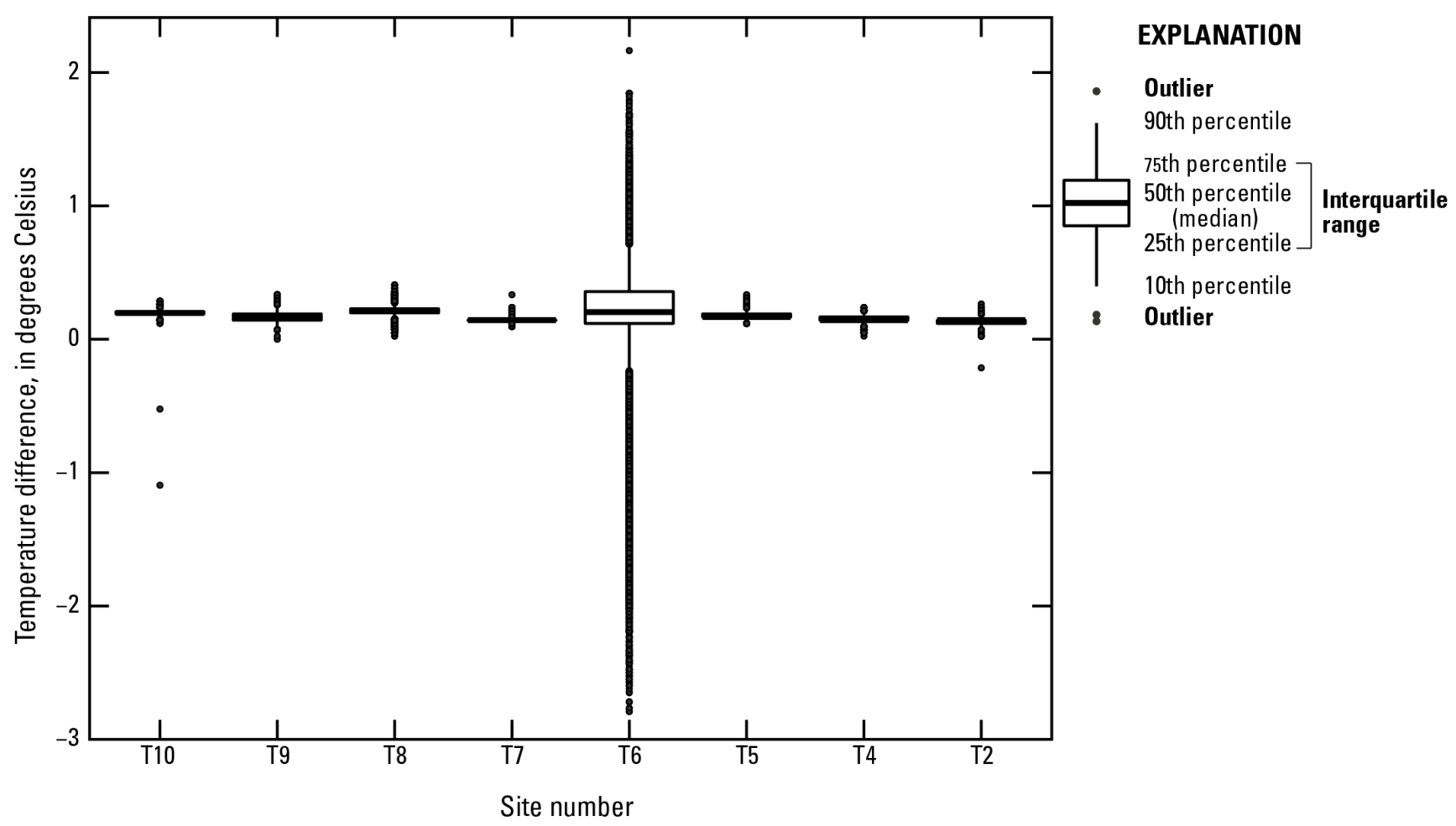

Figure 2. Boxplots of differences between primary and secondary temperature sensors at the nine discrete temperature monitoring sites, lower Quinault River, Olympic National Park, Washington.

Overall changes in stream water temperature and discharge follow expected seasonal changes (figs. 3-6). Maximum water temperatures occurred in late summer; water temperatures decreased beginning in the fall and started to increase again in the spring and throughout the summer.

Streamflows increased from summer baseflow in the fall and were characterized by multiple individual high flow events throughout the winter. Springtime streamflow corresponds to snowmelt, which transitioned back to baseflow in late summer (fig. 3). 


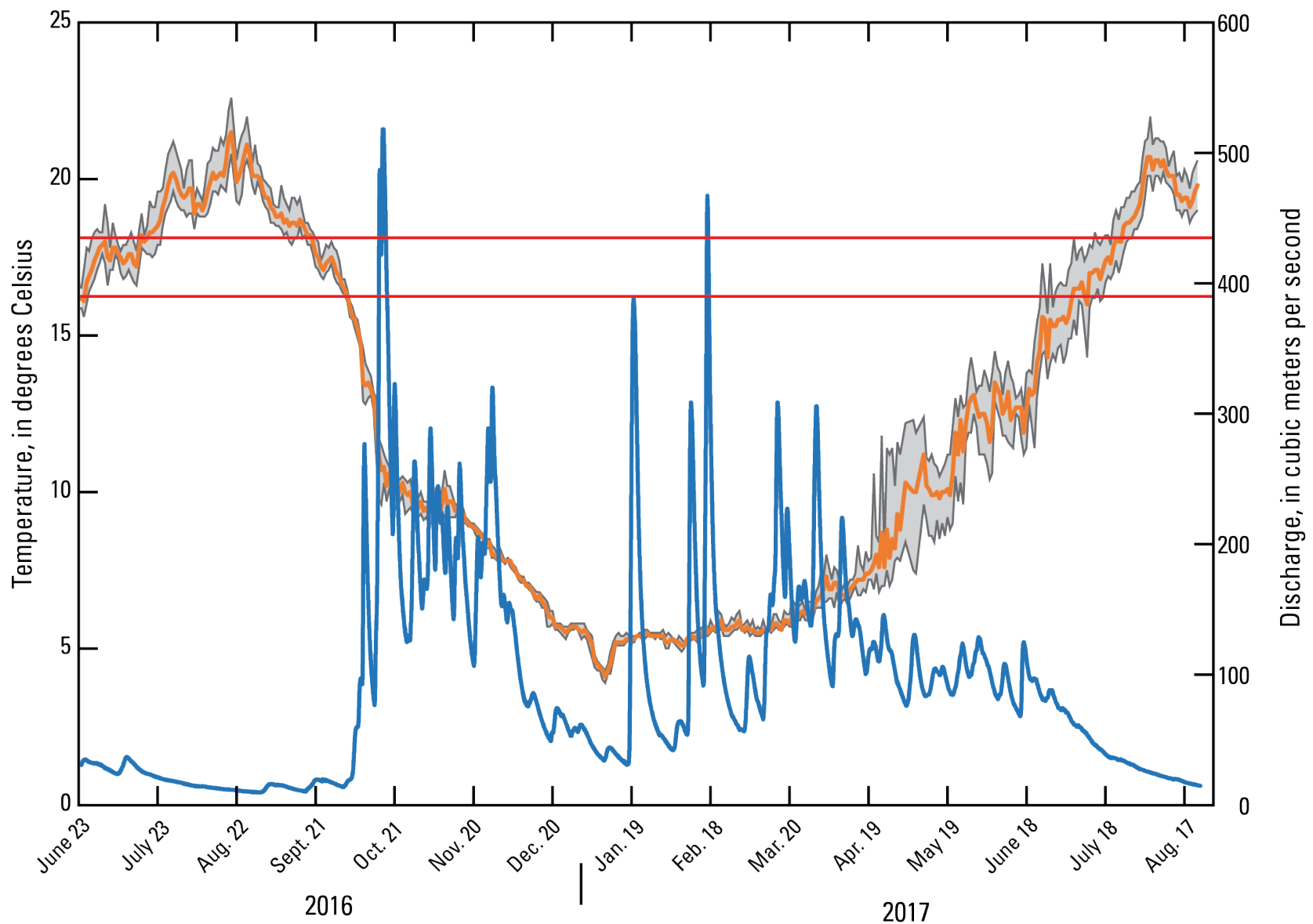

EXPLANATION

Daily minimum/maximum temperature at USGS streamgage

Daily mean temperature at USGS streamgage

Discharge at USGS streamgage

Figure 3. Graph showing discharge and daily mean water temperature at USGS streamgage Quinault River at Quinault Lake (12039500), Olympic Peninsula, Washington, June 2016-August 2017. Shaded area is range between daily minimum and maximum water temperature. Red horizontal lines are at 16 and 17.5 degrees Celsius and correspond to established salmon habitat threshold values for core summer season and for spawning, rearing and migration periods, respectively. 

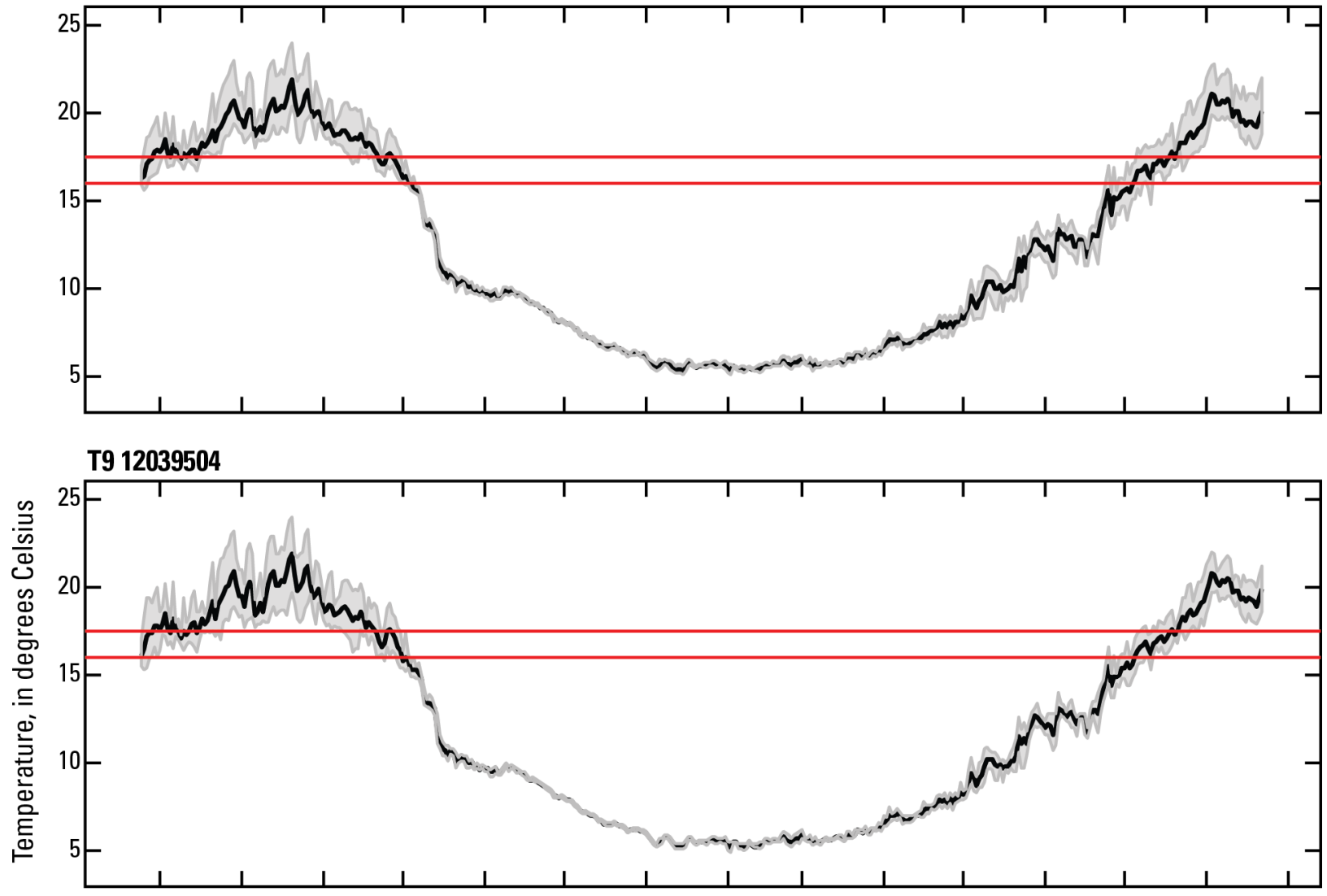

T8 12039507

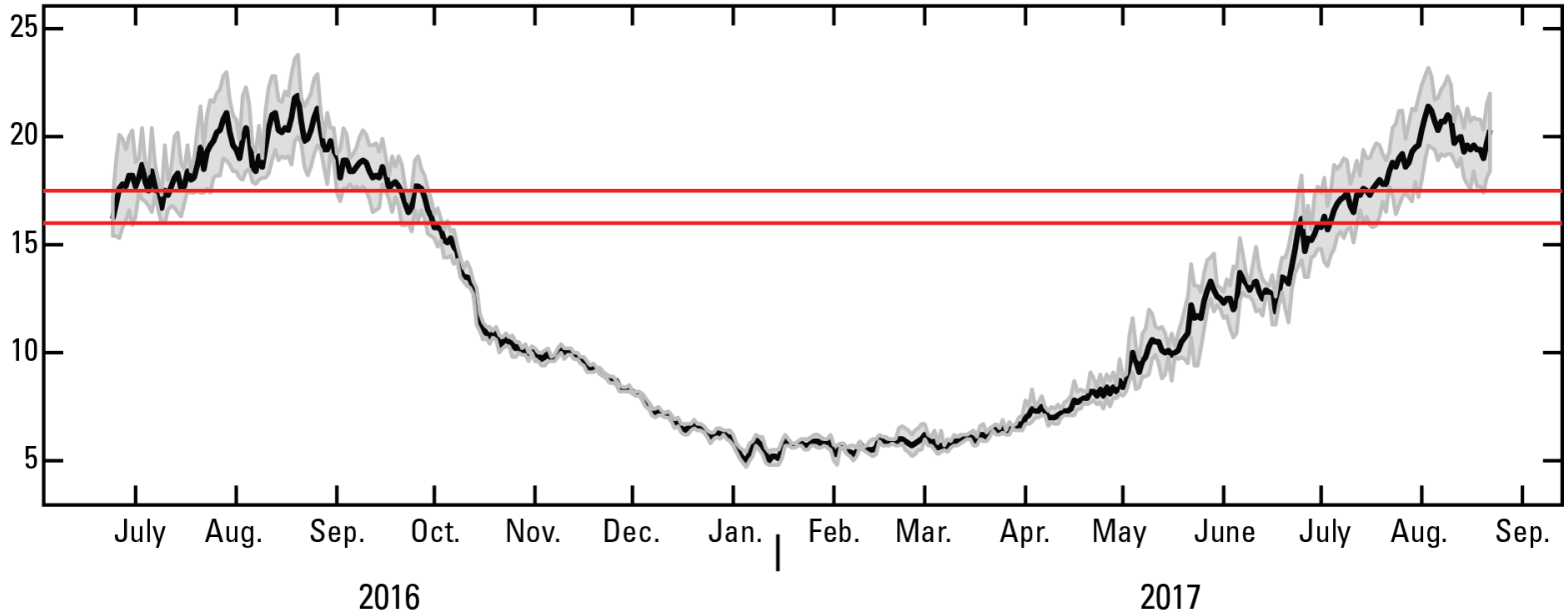

Figure 4. Graphs showing daily mean water temperature at monitoring sites T10, T9, and T8, lower Quinault River, Olympic Peninsula, Washington, June 2016-August 2017. Shaded area is range between daily minimum and maximum water temperature. Red horizontal lines are at 16 and 17.5 degrees Celsius and correspond to established salmon habitat threshold values for core summer season and for spawning, rearing and migration periods, respectively. 
T7 12039509

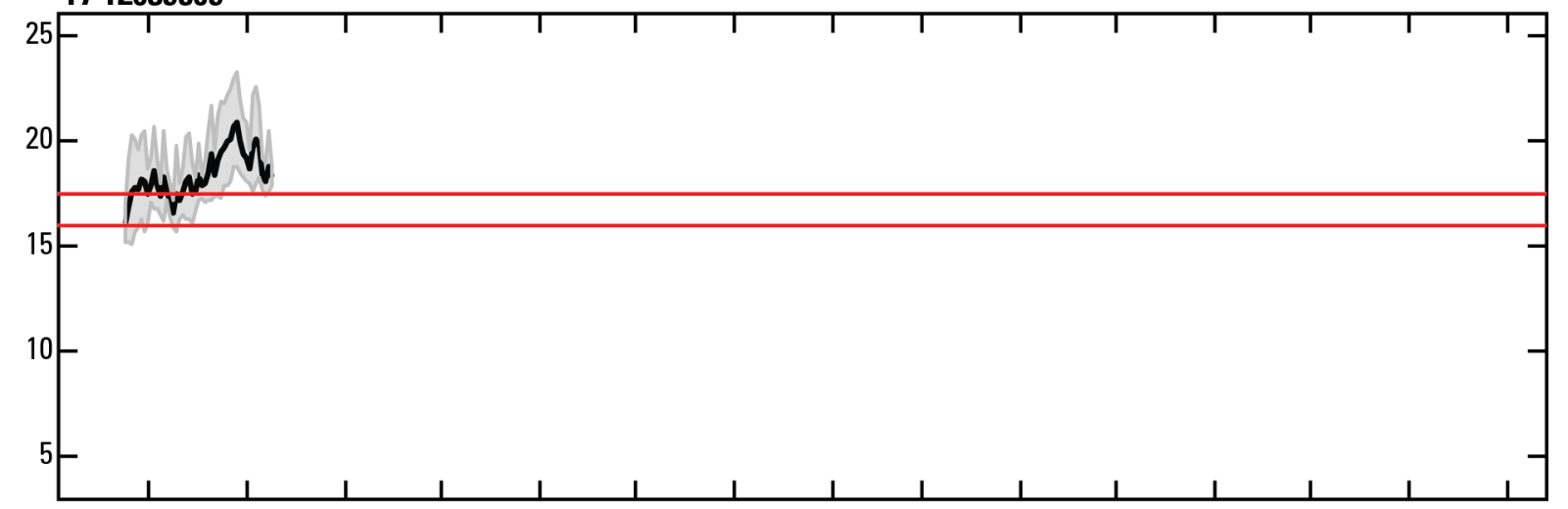

T6 12039511

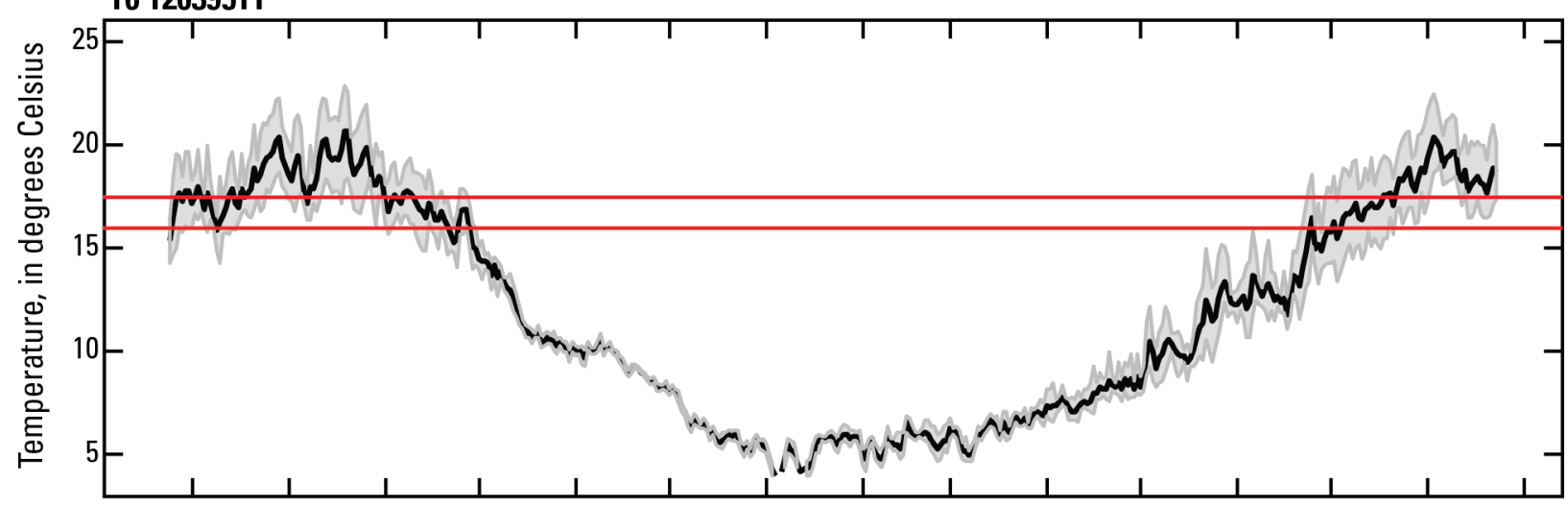

T5 12039514

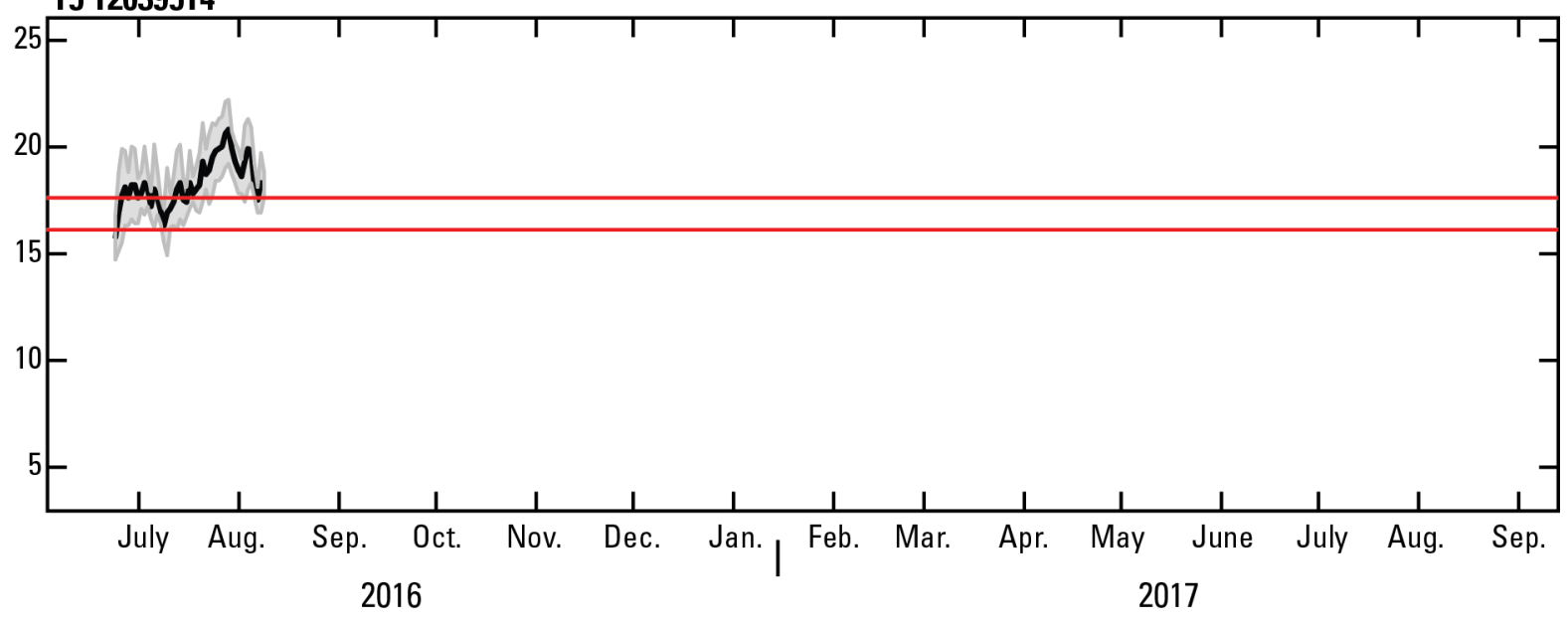

Figure 5. Graphs showing daily mean water temperature at monitoring sites $\mathrm{T7}$, T6, and T5, lower Quinault River, Olympic Peninsula, Washington, June 2016-August 2017. Shaded area is range between daily minimum and maximum water temperature. Red horizontal lines are at 16 and 17.5 degrees Celsius and correspond to established salmon habitat threshold values for core summer season and for spawning, rearing and migration periods, respectively. 

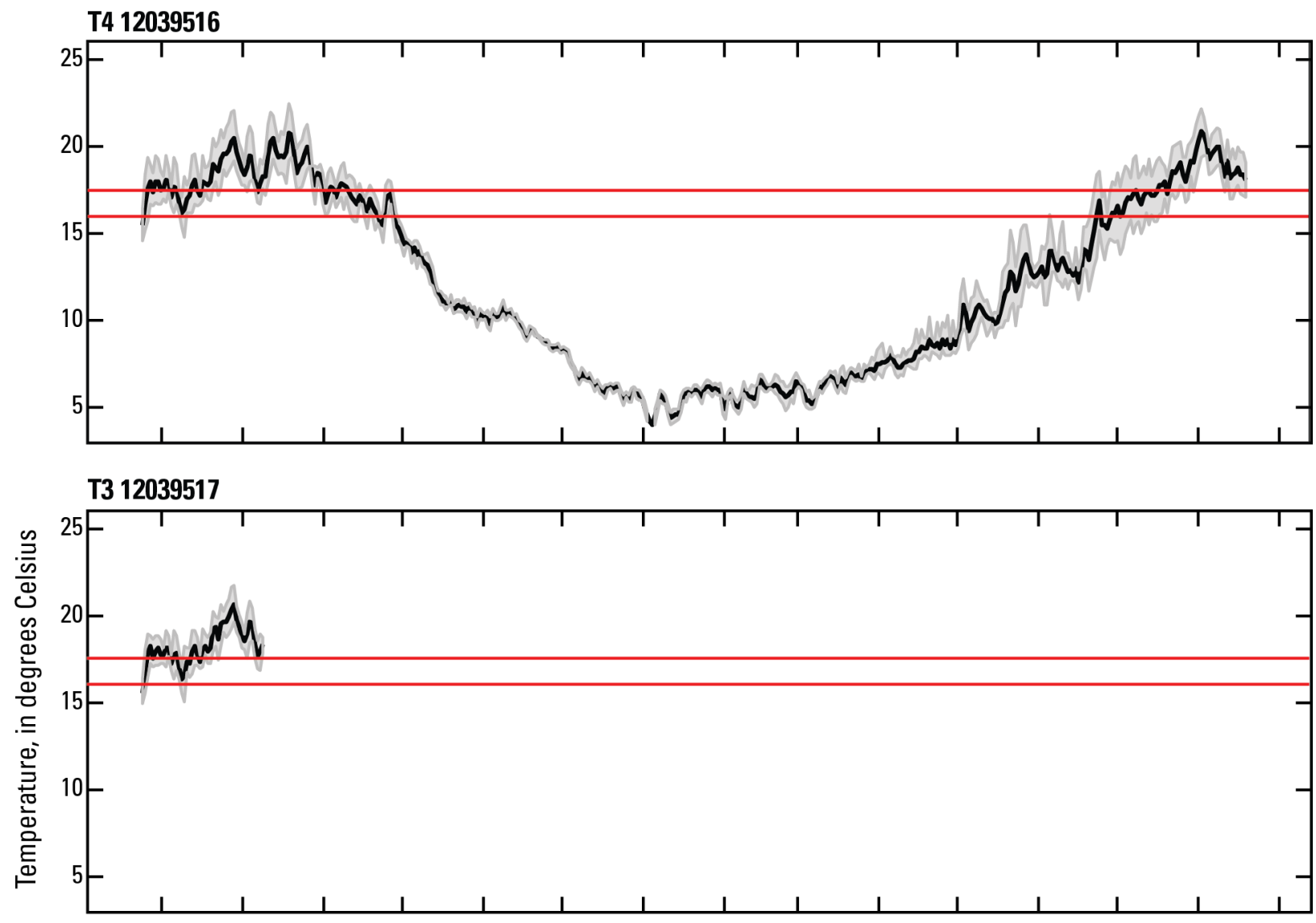

T2 12039518

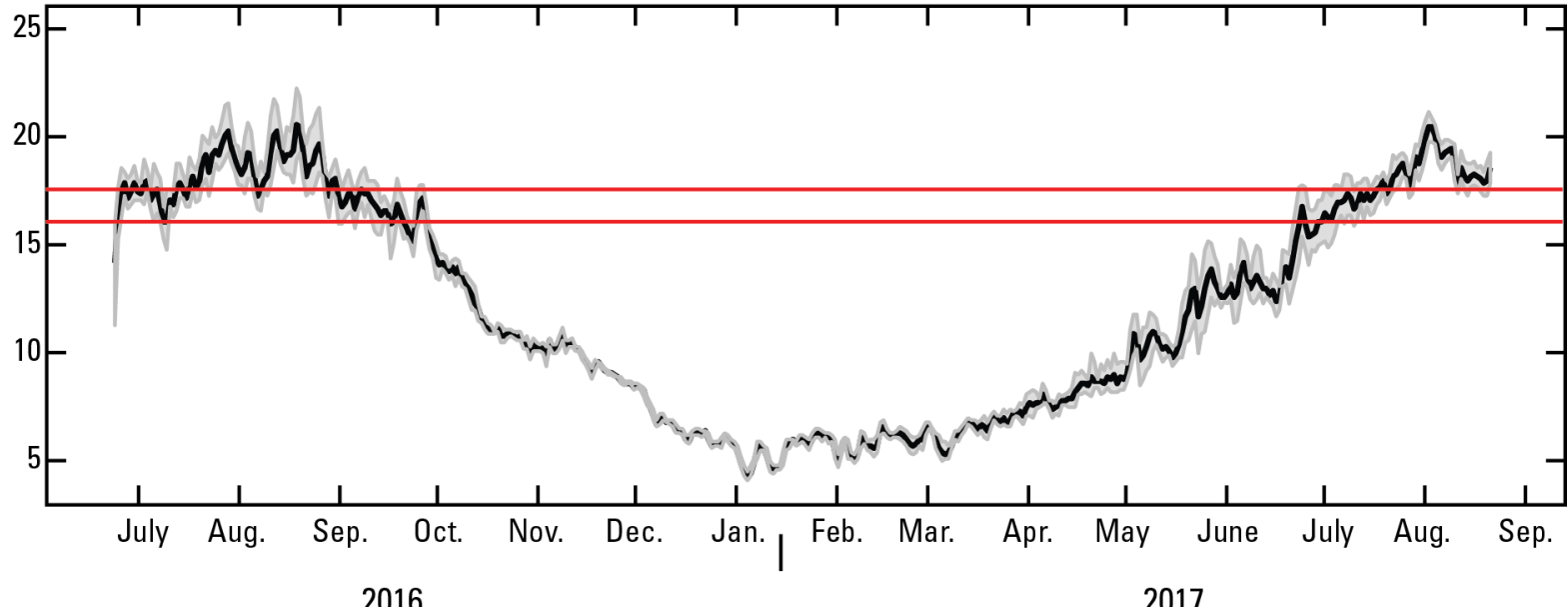

Figure 6. Graphs showing daily mean water temperature at monitoring sites T4, T3, and T2, lower Quinault River, Olympic Peninsula, Washington, June 2016-August 2017. Shaded area is range between daily minimum and maximum water temperature. Red horizontal lines are at 16 and 17.5 degrees Celsius and correspond to established salmon habitat threshold values for core summer season and for spawning, rearing and migration periods, respectively. 
Warm stream temperatures can have negative effects on salmonid species. In a recent study of water temperature in rivers in Washington, Oregon, and California, Fullerton and others (2017) identify cold water as less than $15^{\circ} \mathrm{C}$. The Washington State Department of Ecology identifies a 7-day average of the daily maximum temperatures for each aquatic life use categories, including $16{ }^{\circ} \mathrm{C}$ as the maximum temperature for core summer salmonid habitat and $17.5^{\circ} \mathrm{C}$ for salmonid spawning, rearing, and migration (Washington State Department of Ecology, 2016). Lethal temperatures for Pacific Coast salmonid species have been identified to occur at $24-26^{\circ} \mathrm{C}$, above which individuals will seek coldwater refugia (Richter and Kolmes, 2005).

Daily mean, maximum, and minimum temperatures were calculated from the 15-minute temperature data at all sites (figs. 4-6). Days during which daily minimum temperatures exceeded 16 and $17.5^{\circ} \mathrm{C}$ are reported and thus represent days during which the entire 24-hour period exceeded these threshold temperatures. Daily maximum values greater than $24{ }^{\circ} \mathrm{C}$ are also reported.

Daily minimum temperatures at all sites exceeded $16^{\circ} \mathrm{C}$ beginning in late June or early July and extended through August until late September or early October, occurring on average 124 days during the approximately 15 -month study period (table 3 ). Daily minimum temperatures exceeded $17.5^{\circ} \mathrm{C}$ on average 66 days during the study period. The four most upstream sites, including the USGS streamgage location had the most days during which minimum temperatures exceeded both 16 and $17.5^{\circ} \mathrm{C}$ (figs. 3 and 4). Sustained periods during which water temperatures exceeded $16^{\circ} \mathrm{C}$ at all sites occurred from June 26, 2016, to September 21, 2016 (56 days total) and again from July 5, 2017, until the end of the time series record on August 23, 2017 (49 days total). In 2016, the upstream sites T10, $\mathrm{T} 9$, and $\mathrm{T} 8$ had sustained daily minimum temperatures greater than $16^{\circ} \mathrm{C}$ until September 30,2016 , with the USGS streamgage exceeding $16^{\circ} \mathrm{C}$ until October 4, 2016 (figs. 3 and 4). However, in 2017, daily minimum temperatures remained less than $16^{\circ} \mathrm{C}$ until July 5 at sites T10 and T9 and until July 13 for the upstream USGS streamgage although all other sites downstream had temperatures greater than $16^{\circ} \mathrm{C}$ beginning approximately 2 weeks earlier on June 25, 2017. Daily minimum temperatures exceeded $17.5^{\circ} \mathrm{C}$ intermittently at all sites beginning in July and extending into September at some sites (figs. 3-6). For monitoring sites with a complete data record that included two summer baseflow periods, daily minimum values greater than $17.5^{\circ} \mathrm{C}$ occurred on average for 66 days.

Table 3. Summary of daily temperature values for USGS streamgage Quinault River at Quinault Lake (12039500) and temperature monitoring sites, lower Quinault River, Olympic Peninsula, Washington.

[All values are temperatures in degrees Celsius. Day $\mathrm{T}_{\min }$ and Day $_{\max }$ are the number of days during which daily minimum or maximum temperatures exceeded the specified value]

\begin{tabular}{lllllll}
\hline \multicolumn{1}{c}{ Site } & Mean daily & $\begin{array}{c}\text { Absolute } \\
\text { minimum }\end{array}$ & $\begin{array}{l}\text { Absolute } \\
\text { maximum }\end{array}$ & DayTmin>16 & DayTmin>17.5 & DayTmax $\geq 24$ \\
\hline USGS streamgage & & & & & & \\
$\quad(12039500)$ & 12.1 & 3.9 & 22.6 & 142 & 97 & 0 \\
T10 & 12.2 & 5.1 & 24 & 139 & 89 & 1 \\
T9 & 12.1 & 4.9 & 24 & 139 & 74 & 1 \\
T8 & 12.3 & 4.7 & 23.8 & 129 & 69 & 0 \\
${ }^{1}$ T7 & 18.4 & 15.1 & 23.3 & 39 & 15 & 0 \\
T6 & 11.9 & 3.4 & 22.9 & 97 & 32 & 0 \\
${ }^{1}$ T5 & 18.2 & 14.6 & 22.1 & 41 & 13 & 0 \\
T4 & 12.1 & 3.6 & 22.5 & 116 & 51 & 0 \\
${ }^{1}$ T3 & 18.2 & 14.9 & 21.7 & 43 & 17 & 0 \\
T2 & 12.0 & 4 & 22.2 & 121 & 49 & 0 \\
\hline
\end{tabular}

${ }^{1}$ Incomplete temperature record that is limited to only part of summer 2016. 
During summer 2016, daily maximum temperatures periodically exceeded $20^{\circ} \mathrm{C}$ at sites $\mathrm{T} 10$ and T9 on June 26 (figs. 3-4). All sites exceeded $20^{\circ} \mathrm{C}$ from July 26 to 30 and again from August 11 to 21 (figs. 3-6). Maximum temperatures were highest $\left(>23{ }^{\circ} \mathrm{C}\right.$ ) at sites T10, T9, and T8 for two 2-3 day periods in late August 2016. During summer 2017, daily maximum temperatures began to exceed $20^{\circ} \mathrm{C}$ by July 23, 2017, at sites T8 and T4 and all sites exceeded $20^{\circ} \mathrm{C}$ from August 1 to 11,2017 . The upstream sites that included the USGS streamgage and sites T10-T8 had maximum daily temperatures greater than $20^{\circ} \mathrm{C}$ until the end of the times series record on August 23, 2017.

August water temperature values for 2016 and 2017 , which exceeded $16^{\circ} \mathrm{C}$ at all monitoring sites and $17.5^{\circ} \mathrm{C}$ for most of the month at all sites, were higher in the lower Quinault River than the model predictions by NorWeST for the historical period of 1993-2011 (Isaak and others, 2011), which ranges from 11 to $15^{\circ} \mathrm{C}$. These model-predicted data are likely based on nearby basins with similar predictor variables, which may not account for the effect of Lake Quinault. Therefore, analysis relying on NorWeST model-predicted water temperatures from the historical period for the lower Quinault River will result in an underestimate, in some cases by more than $2{ }^{\circ} \mathrm{C}$.

\section{Coarse-Scale Downstream Trends in Water Temperature}

For study sites with a complete 15-month record, summertime (July-September) water temperatures were generally cooler in the downstream direction along the lower Quinault River, but generally increased in the downstream direction during the rest of the year, which may indicate groundwater influences that mitigate the effects of Lake Quinault (fig. 7). Daily mean and maximum temperatures were coolest in the downstream direction and the number of days during which minimum temperatures exceeded 16 and $17.5^{\circ} \mathrm{C}$ consistently decreased in the downstream direction with few exceptions (table 3 ). The generally low water temperature values at site $\mathrm{T} 6$ may be attributed to the close proximity of the sensor location to a pool, however, temperature cross sections during the June 2016 and August 2017 field visits indicate consistency with the sensor location. Consequently, the temperature sensor at site $\mathrm{T} 6$ is considered representative of the river at this location and suggests a cooler region of the river relative to the immediate upstream and downstream monitoring sites. Downstream cooling trends were most prominent during August and September (fig. 7). The four most upstream monitoring sites exhibited consistent decreases in daily minimum temperatures during August and September, and somewhat in July, although the site T8 exhibited slightly higher water temperatures relative to the upstream site T9. Site T8 is on a shallowly inundated mid-channel bar that likely experiences full sun exposure. Downstream of site T8, however, the three downstream sites with complete 15-month records, were cooler than upstream, but did not exhibit consistent downstream trends (fig. 7). Water temperatures increase in the downstream direction during the fall (October and November) and spring (March-June).

Seasonal differences in water temperatures between upstream and downstream sections of the lower Quinault River may be attributed to differential influences of Lake Quinault and groundwater. Specifically, Lake Quinault appears to have a warming effect on water temperature during the summer and a mild cooling effect during the other times of the year. With increasing distance from the lake, groundwater influences may buffer the lake's effect, cooling water that had been warmed by the lake during the summer and potentially contributing warmer water during winter. Small tributaries draining into the lower Quinault River may also influence downstream trends. 


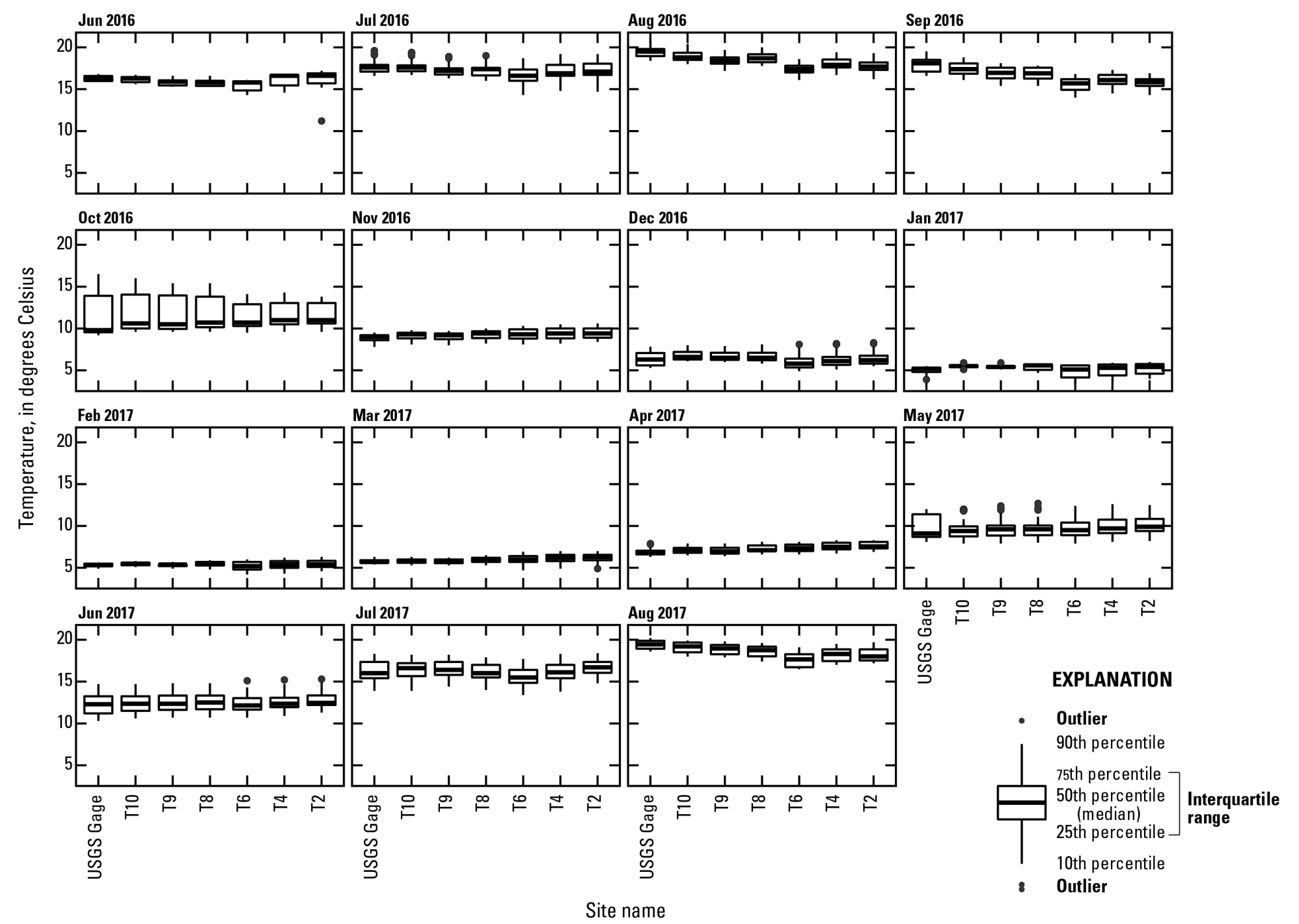

Figure 7. Boxplots of daily minimum temperatures at USGS streamgage Quinault River at Quinault Lake (12039500) and the six sites with complete data over the 15-month study period, lower Quinault River, Olympic Peninsula, Washington, June 2016-August 2017. 


\section{Longitudinal Temperature Profile}

The longitudinal profile for depth and the water surface and near-streambed temperatures were measured from August 9 to 12, 2016 (Jaeger and others, 2018). Depth values are missing for locations where the Solinst Levelogger was temporarily removed from the channel to avoid obstructions such as large wood. Concurrent near-streambed temperature data are missing for three extended periods on August 12, when the longitudinal survey was interrupted for tens of minutes or more. During shorter interruptions (a few minutes) when depth values are missing, care should be taken to evaluate nearstreambed temperature concurrent with and immediately following temporary removal of the Solinst Levelogger from the channel to account for potential lagged responses in temperature adjustment back to stream water temperatures after removal.

Theoretically, a longitudinal thermal profile tracks a parcel of water traveling downstream during the day; departures from the diurnal heating cycle may indicate relatively large changes in water depth, groundwater or tributary input, or riparian shading. Departures from the diurnal heating cycle are strongest during late summer baseflow conditions and maximum daily air temperatures. The longitudinal temperature survey was done from August 9 to 12, 2016, during baseflow conditions. Cool and rainy conditions on August 7 and 8 preceded the survey; during the survey, cloudy and dry conditions occurred on August 9 and warm, sunny conditions persisted from August 10 through 12. Mean daily streamflow measured at the USGS streamgage 12039500 ranged from 13.3 to $14.1 \mathrm{~m}^{3} / \mathrm{s}$ (471-499 ft 3 /s) from August 9 to August 12, 2016 (U.S. Geological Survey, 2018). Maximum daily stream water temperature at this streamgage ranged from 19.3 to $20.6{ }^{\circ} \mathrm{C}$ during this period.

Near-streambed temperatures along the longitudinal profile indicate a diurnal warming effect represented by a progressive downstream increase in temperature values on each individual survey day (fig. 8). The abrupt mapped change from warm to cool temperatures near RK 30 corresponds to where the August 10 survey ended and the August 11 survey began, reflecting relatively warm temperatures in late afternoon on August 10 and cooler temperatures during the morning on August 11. The magnitude of the diurnal near-streambed temperature cycle over the longitudinal survey period at the upstream and downstream extents of the surveyed area is shown in figure 9. 


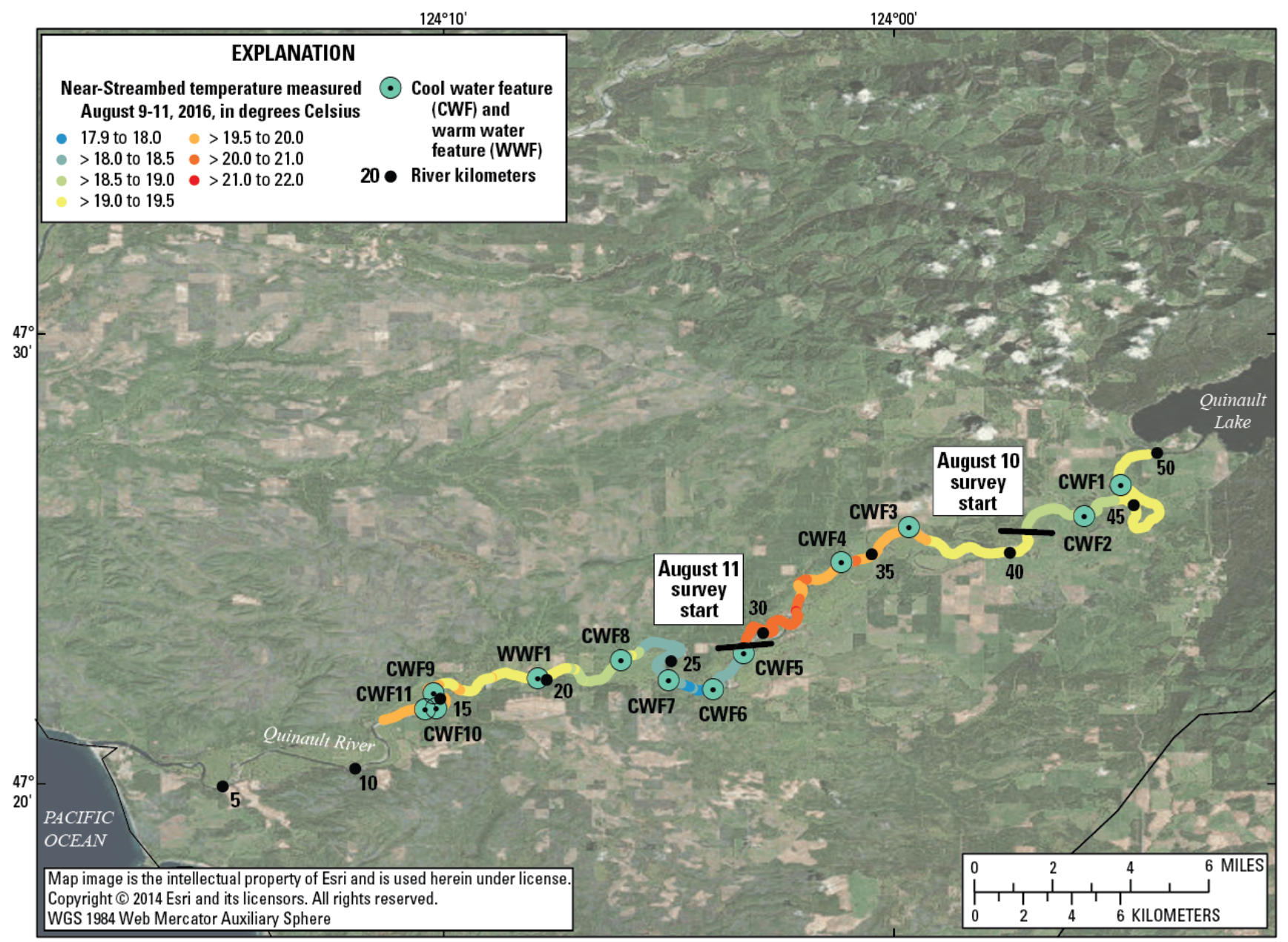

Figure 8. Orthoimage showing location of near-streambed temperatures during the longitudinal profile survey and 11 potential cool water features and 1 warm water feature along the lower Quinault River (river kilometer 13-50), Olympic Peninsula, Washington, August 9-11, 2016. Data were not georeferenced on August 12. 


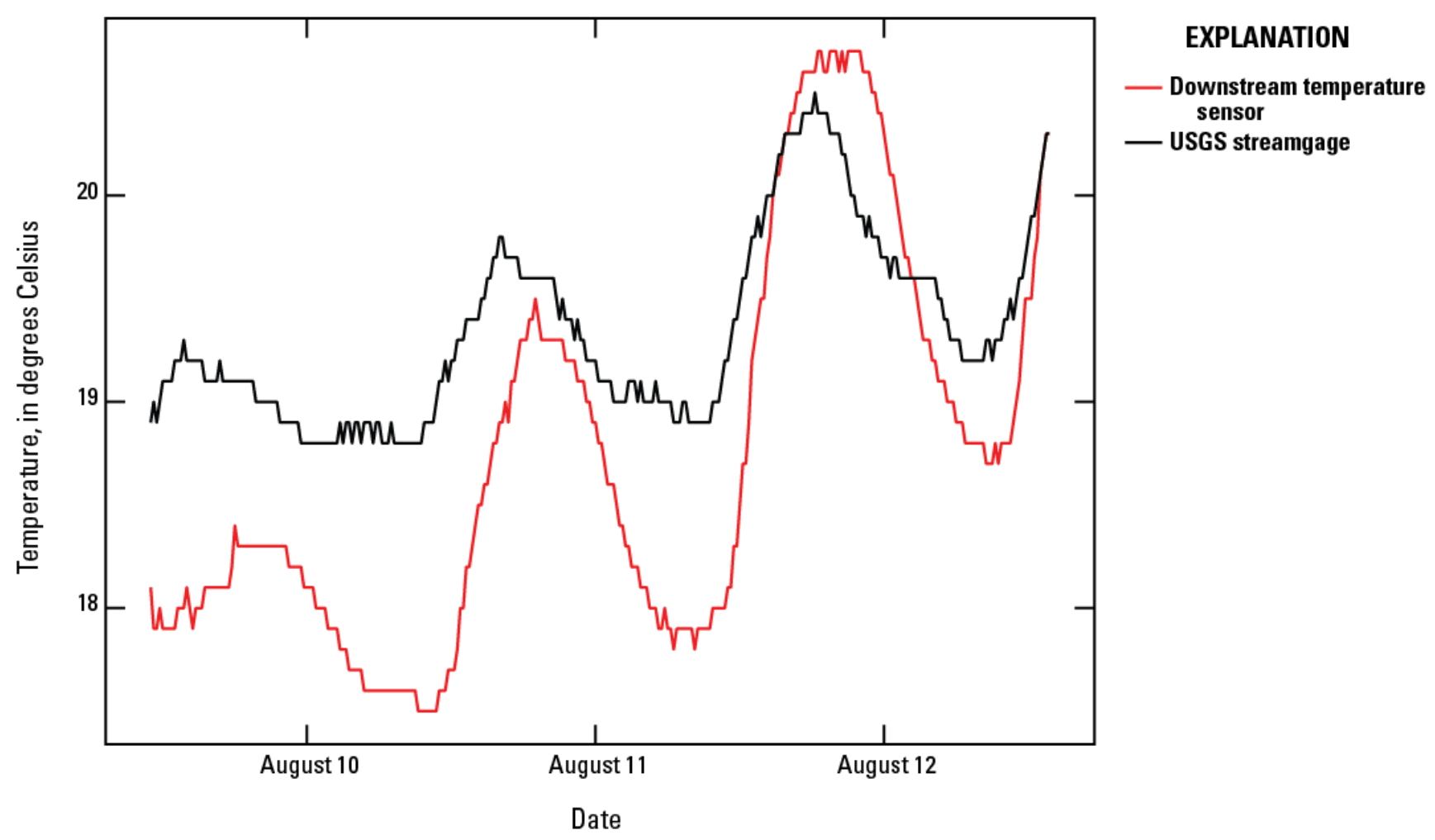

Figure 9. Graph showing water temperature at the USGS streamgage Quinault River at Quinault Lake (12039500) and an Onset ${ }^{\circledR}$ Hobo temperature sensor deployed at the downstream extent of the longitudinal profile to represent magnitude of the diurnal cycle, lower Quinault River, Olympic Peninsula, Washington, August 9-12, 2016.

Near-streambed temperatures from the longitudinal profile ranged from 17.9 to $21.7^{\circ} \mathrm{C}$; watersurface temperatures ranged from 18.3 to $24.2^{\circ} \mathrm{C}$ (fig. 10). Near-streambed temperatures sometimes, but not always, decreased with greater water depths (fig. 10). Water depths were generally shallow $(<2 \mathrm{~m})$, did not exceed $6 \mathrm{~m}$, and increased in the downstream direction during the survey period. No cold water refugia with more than $3{ }^{\circ} \mathrm{C}$ departure from ambient stream temperatures were identified, but CWFs with at least $0.1^{\circ} \mathrm{C}$ lower temperatures than adjacent waters were identified throughout the lower Quinault River. Identified reaches of CWFs extended over approximate distances of 100-600 m, and appeared to indicate more diffuse as opposed to discrete groundwater influences (for example, Vaccaro and Maloy, 2006). 


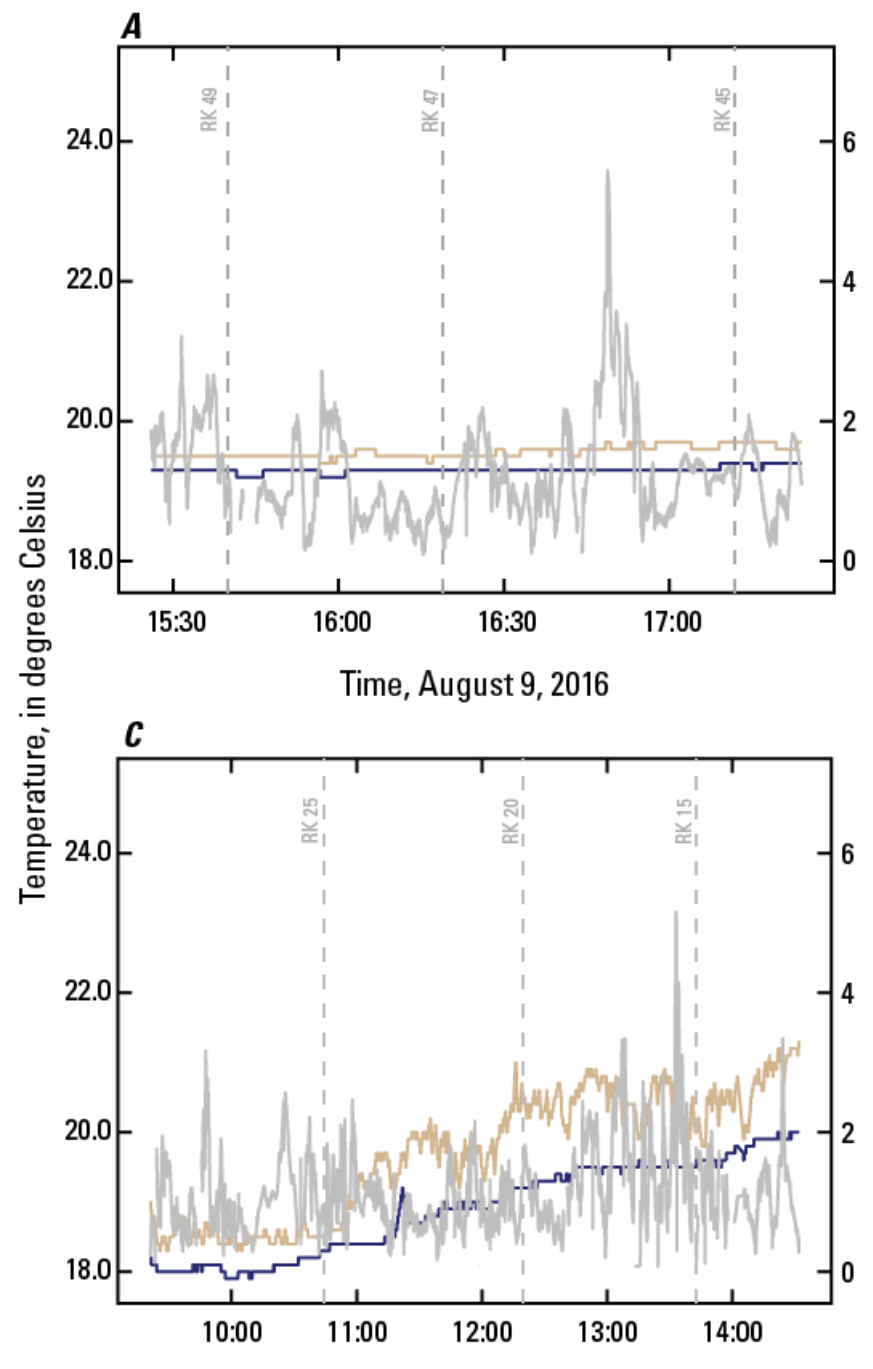

Time, August 11, 2016
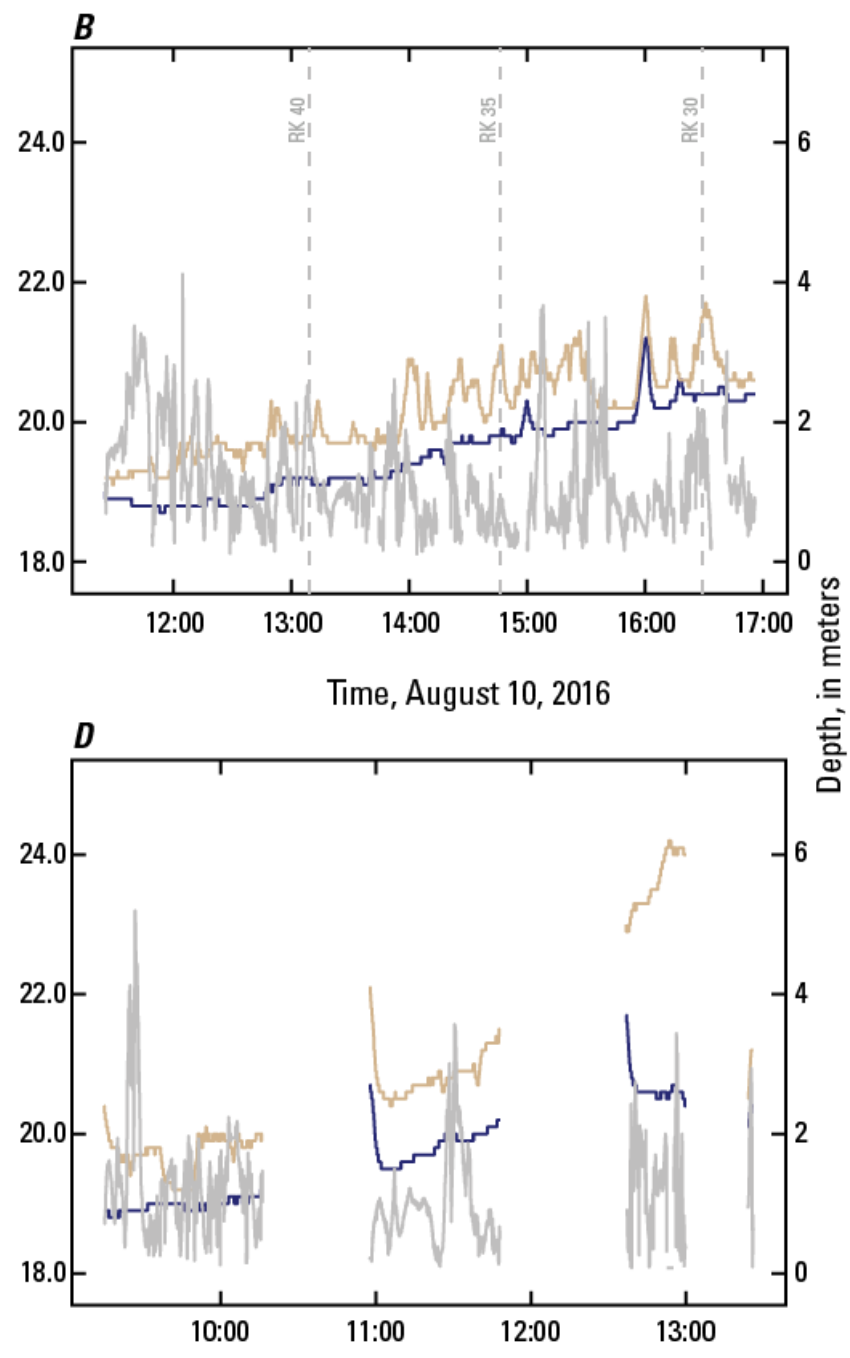

Time, August 12, 2016

EXPLANATION

Depth

Near-streambed temperature

Water surface temperature

Figure 10. Graphs showing surface and near-streambed water temperatures, and water depth during the longitudinal profile survey along the lower Quinault River (approximately river kilometers 13-49), Olympic Peninsula, Washington, August 9-12, 2016. Dashed vertical lines delineate approximate location of river kilometers for August 9-11. 


\section{Characterization of Reach-Scale Cooler Water Features}

Given the absence of distinct cold-water regions within the lower Quinault River, 11 locations along the lower Quinault River were identified from the longitudinal temperature profile at which subtle changes in the temperature profile $\left(0.1^{\circ} \mathrm{C}\right)$ suggested a potential CWF that corresponded to a local geomorphic feature, such as a tributary confluence, an extended pool, a pool associated with a meander bend, or large in-channel wood (fig. 8, table 4). On August 22-24, 2017, 10 of the 11 CWFs were surveyed. The most upstream feature, CFW 1 was surveyed on August 29, 2017, during cooler conditions.

Cross section temperatures from the field surveys suggested that 8 of the 11 identified potential CWFs maintained cooler near-streambed temperatures relative to upstream and downstream conditions, although cross section averaged temperatures between the CWF and upstream and downstream locations were often subtle $\left(0.2^{\circ} \mathrm{C}\right.$ or less; table 4$)$. Five of the eleven CWFs maintained cooler water temperatures along one side of the channel, which was associated with riparian shading or shading from steep river banks. Differences in temperature measurements between the channel margins at these shade-associated CWFs were on average $0.6^{\circ} \mathrm{C}$, ranging from 0.4 to $0.9{ }^{\circ} \mathrm{C}$. The longitudinal survey occurred along the thalweg and therefore near-streambed temperatures represent the deepest portion of the river at a cross section. However, water temperatures along shallow margins remained cooler when associated with river bank or riparian shading, and cross sections from two of the CWFs indicated that the channel geometry was a shallow glide and therefore cooler waters were not a result of deeper water.

Four CWFs identified from the longitudinal profile were associated with specific geomorphic features that included the confluences of a cool secondary channel or a cold-water tributary or were associated with large, in-channel wood (table 4). At approximately RK30 immediately upstream of CWF 5, the lower Quinault River flows through an extended floodplain complex in which the channel morphology includes secondary channels (fig. 8). Average temperatures were $0.25{ }^{\circ} \mathrm{C}$ cooler in the secondary channel relative to the main channel and water temperatures were $0.5^{\circ} \mathrm{C}$ cooler along the left side of the main channel at the confluence of the secondary channel, which coincided with a deep, shaded pool. Conversely, field surveys of CWF 11, which also was identified as associated with the confluence of a side channel, did not detect temperature differences between the tributary and the main stem at the confluence suggesting a limited influence of the side channel as a cooling effect on the main stem at this location. CWF 6 was identified at the confluence of an unnamed tributary at RK27. Average temperatures in the main channel immediately upstream of the tributary confluence were $18.6^{\circ} \mathrm{C}$; average temperatures in the tributary were $14.9^{\circ} \mathrm{C}$ representing a $3.7^{\circ} \mathrm{C}$ temperature difference. Downstream of the confluence, cooler temperatures were limited to the left side of the cross section and the average temperature was $18.6^{\circ} \mathrm{C}$, which was the same as the upstream cross section, suggesting that the contribution of the tributary is relatively local and does not extend bank to bank in the mainstem. Finally, CWF 9 was identified at approximately RK15 and associated with a reach that was relatively deep and contained large, in-channel wood jams along the right bank, and is referred to here as a large, in-channel wood corridor. Water temperatures were consistently 17.0-17.1 ${ }^{\circ} \mathrm{C}$ along the full length of all cross sections throughout the feature and were almost $1{ }^{\circ} \mathrm{C}$ cooler than water temperatures downstream, including the exposed right side of the channel in CWF 10, immediately downstream of CWF 9. 
Table 4. Depth and near-streambed temperature at cross sections along potential cool water features and one potential warm water feature (WWF) in the lower Quinault River, Olympic Peninsula, Washington, June 2016-August 2017.

[All depths are in meters and all temperature are in degrees Celsius; Five depth and temperature measurements were taken along each cross section including at the left bank (LB), left of channel center (CL), channel center (C), right of channel center (CR), and at the right bank (RB). Type, river kilometer: Geomorphic character of the cool water features (CWF) and river kilometer. Feature No.: Features listed in the downstream direction. Cross section No.: Numbers listed in the downstream direction and include main channel (MC) and side channel (SC). Temp, LB - Temp, RB is the absolute difference between temperatures between left bank and right bank]

\begin{tabular}{|c|c|c|c|c|c|c|c|c|c|c|c|c|c|c|}
\hline $\begin{array}{l}\text { Type, river- } \\
\text { kilometer }\end{array}$ & $\begin{array}{c}\text { Feature } \\
\text { No. }\end{array}$ & $\begin{array}{c}\text { Cross } \\
\text { section No. }\end{array}$ & $\begin{array}{l}\text { Depth, } \\
\text { LB }\end{array}$ & $\begin{array}{l}\text { Depth, } \\
\text { CL }\end{array}$ & $\begin{array}{l}\text { Depth, } \\
\text { C }\end{array}$ & $\begin{array}{l}\text { Depth, } \\
\text { CR }\end{array}$ & $\begin{array}{l}\text { Depth, } \\
\text { RB }\end{array}$ & $\begin{array}{c}\text { Maximum } \\
\text { depth }\end{array}$ & $\begin{array}{c}\text { Temp, } \\
\text { LB }\end{array}$ & $\begin{array}{c}\text { Temp, } \\
\text { CL }\end{array}$ & $\begin{array}{c}\text { Temp, } \\
\text { C }\end{array}$ & $\begin{array}{c}\text { Temp, } \\
\text { CR }\end{array}$ & $\begin{array}{c}\text { Temp, } \\
\text { RB }\end{array}$ & $\begin{array}{l}\text { Temp, LB } \\
\text { temp, RB }\end{array}$ \\
\hline \multirow{5}{*}{$\begin{array}{l}\text { Extended pool } \\
\text { - shaded, } \\
48\end{array}$} & CWF1 & Trans1 & 0.58 & 0.43 & 1.07 & 1.16 & 0.15 & 1.16 & 21.6 & 21.4 & 21.2 & 21.1 & 20.8 & 0.8 \\
\hline & CWF1 & Trans2 & 0.30 & 0.88 & 1.71 & 1.13 & 0.24 & 1.71 & 22 & 21.7 & 21.5 & 21.1 & 20.8 & 1.2 \\
\hline & CWF1 & Trans3 & 0.37 & 1.80 & 2.74 & 1.65 & 0.52 & 2.74 & 21.7 & 21.6 & 21.2 & 21 & 21 & 0.7 \\
\hline & CWF1 & Trans4 & 0.12 & 0.73 & 1.43 & 2.41 & 0.85 & 2.41 & 21.8 & 21.5 & 21.5 & 21.3 & 21.1 & 0.7 \\
\hline & CWF1 & Trans5 & 0.20 & 0.52 & 1.16 & 1.16 & 0.67 & 1.16 & 22.2 & 21.4 & 21 & 21.2 & 21.1 & 1.1 \\
\hline \multirow{7}{*}{$\begin{array}{l}\text { Meander bend } \\
\text { - shaded, } \\
43\end{array}$} & CWF2 & Trans1 & 0.61 & 1.83 & 1.52 & 1.22 & 0.76 & 1.83 & 19.7 & 19.8 & 19.8 & 19.9 & 20 & 0.3 \\
\hline & CWF2 & Trans2 & 1.22 & 2.13 & 2.13 & 1.07 & 0.30 & 2.13 & 19.6 & 19.6 & 19.7 & 19.8 & 19.9 & 0.3 \\
\hline & CWF2 & Trans3 & 1.83 & 2.13 & 1.52 & 1.22 & 0.46 & 2.13 & 19.8 & 19.9 & 20 & 20.1 & 20.2 & 0.4 \\
\hline & CWF2 & Trans4 & 4.27 & 3.66 & 1.52 & 0.76 & 0.30 & 4.27 & 19.7 & 19.8 & 19.9 & 20 & 20.1 & 0.4 \\
\hline & CWF2 & Trans5 & 2.59 & 2.44 & 1.83 & 1.07 & 0.30 & 2.59 & 19.8 & 19.9 & 20 & 20.1 & 20.2 & 0.4 \\
\hline & CWF2 & Trans6 & 3.05 & 2.74 & 2.13 & 0.76 & 0.30 & 3.05 & 19.8 & 19.9 & 19.9 & 20 & 20.1 & 0.3 \\
\hline & CWF2 & Trans 7 & 3.66 & 3.96 & 2.44 & 1.52 & 0.61 & 3.96 & 19.9 & 19.9 & 20 & 20.1 & 20.2 & 0.3 \\
\hline \multirow{4}{*}{$\begin{array}{l}\text { Meander } \\
\text { bend, } \\
36\end{array}$} & CWF3 & Trans1 & 0.12 & 0.37 & 0.46 & 0.61 & 1.52 & 1.52 & 21.5 & 20.8 & 20.8 & 21 & 20.9 & 0.6 \\
\hline & CWF3 & Trans2 & 0.30 & 0.91 & 1.83 & 1.22 & 0.30 & 1.83 & 20.9 & 20.9 & 20.9 & 20.8 & 20.6 & 0.3 \\
\hline & CWF3 & Trans3 & 0.15 & 0.46 & 0.61 & 1.83 & 1.22 & 1.83 & 20.8 & 20.9 & 20.9 & 20.8 & 20.9 & 0.1 \\
\hline & CWF3 & Trans4 & 0.15 & 0.46 & 1.22 & 2.13 & 1.83 & 2.13 & 20.9 & 20.9 & 20.9 & 20.9 & 20.9 & 0 \\
\hline \multirow{5}{*}{$\begin{array}{l}\text { Floodplain } \\
\text { complex, } \\
30\end{array}$} & CWF5 & Trans1_MC & 0.13 & 0.46 & 0.76 & 1 & 1 & 0.76 & 18.7 & 18 & 18 & 1 & 1 & NA \\
\hline & CWF5 & Trans2_MC & 0.30 & 0.49 & 0.55 & 1 & 1 & 0.55 & 18.2 & 18.1 & 18.1 & 1 & 1 & NA \\
\hline & CWF5 & Trans3_MC & 1.52 & 0.91 & 0.50 & 0.27 & 0.15 & 1.52 & 18.2 & 18.5 & 18.3 & 18.4 & 18.7 & 0.5 \\
\hline & CWF5 & Trans1_SC & 0.30 & 0.09 & 0.27 & 0.52 & 0.38 & 0.52 & 18.8 & 17.7 & 17.7 & 17.9 & 18.1 & 0.7 \\
\hline & CWF5 & Trans2 SC & 0.61 & 0.46 & 0.76 & 1.22 & 1.07 & 1.22 & 17.8 & 17.9 & 17.9 & 17.9 & 17.9 & 0.1 \\
\hline
\end{tabular}




\begin{tabular}{|c|c|c|c|c|c|c|c|c|c|c|c|c|c|c|}
\hline $\begin{array}{l}\text { Type, river- } \\
\text { kilometer }\end{array}$ & $\begin{array}{c}\begin{array}{c}\text { Feature } \\
\text { No. }\end{array} \\
\end{array}$ & $\begin{array}{c}\text { Cross } \\
\text { section No. }\end{array}$ & $\begin{array}{l}\text { Depth, } \\
\text { LB }\end{array}$ & $\begin{array}{l}\text { Depth, } \\
\text { CL }\end{array}$ & $\begin{array}{c}\text { Depth, } \\
\text { C }\end{array}$ & $\begin{array}{c}\text { Depth, } \\
\text { CR } \\
\end{array}$ & $\begin{array}{l}\text { Depth, } \\
\text { RB } \\
\end{array}$ & $\begin{array}{c}\text { Maximum } \\
\text { depth }\end{array}$ & $\begin{array}{c}\text { Temp, } \\
\text { LB }\end{array}$ & $\begin{array}{c}\text { Temp, } \\
\text { CL }\end{array}$ & $\begin{array}{c}\text { Temp, } \\
\text { C }\end{array}$ & $\begin{array}{c}\text { Temp, } \\
\text { CR }\end{array}$ & $\begin{array}{c}\text { Temp, } \\
\text { RB } \\
\end{array}$ & $\begin{array}{l}\text { Temp, LB - } \\
\text { temp, RB }\end{array}$ \\
\hline \multirow{4}{*}{$\begin{array}{l}\text { Tributary } \\
\text { confluence, } \\
27\end{array}$} & CWF6 & Trans 1 & 0.61 & 1.52 & 0.76 & 0.61 & 0.30 & 1.52 & 18.5 & 18.6 & 18.5 & 18.5 & 18.6 & 0.1 \\
\hline & CWF6 & Trans2 & 0.30 & 0.61 & 1.22 & 0.76 & 0.15 & 1.22 & 16.9 & 17 & 17.1 & 18.3 & 18.7 & 1.8 \\
\hline & CWF6 & Trans3 & 0.61 & 0.91 & 1.22 & 0.46 & 0.15 & 1.22 & 17.5 & 17.4 & 18.7 & 18.9 & 20.4 & 2.9 \\
\hline & CWF6 & Trans1_Trib & 0.30 & 0.15 & 0.15 & 0.15 & 0.15 & 0.30 & 14.7 & 14.6 & 14.7 & 14.9 & 15.4 & 0.7 \\
\hline \multirow{4}{*}{$\begin{array}{l}\text { Shallow glide } \\
\text { - shaded, } \\
25\end{array}$} & CWF7 & Trans1 & 1.22 & 2.13 & 1.52 & 2.59 & 0.61 & 2.59 & 19 & 19.1 & 19.1 & 19.2 & 19.3 & 0.3 \\
\hline & CWF7 & Trans2 & 1.22 & 1.83 & 1.52 & 0.76 & 0.46 & 1.83 & 19 & 19.2 & 19.4 & 19.4 & 19.5 & 0.5 \\
\hline & CWF7 & Trans3 & 0.91 & 1.68 & 1.52 & 1.37 & 0.46 & 1.68 & 19.5 & 18.9 & 19 & 19.1 & 19.3 & 0.2 \\
\hline & CWF7 & Trans4 & 2.13 & 2.44 & 1.52 & 1.07 & 0.37 & 2.44 & 19 & 19.1 & 19.4 & 19.5 & 19.7 & 0.7 \\
\hline \multirow{2}{*}{$\begin{array}{r}\text { Shallow glide } \\
\text { - shaded, } 22 \\
\end{array}$} & CWF8 & Trans1 & 0.23 & 0.27 & 0.21 & 0.52 & 0.70 & 0.70 & 19.7 & 19.7 & 19.7 & 19.7 & 19.6 & 0.1 \\
\hline & CWF8 & Trans2 & 0.24 & 0.47 & 0.62 & 0.73 & 0.82 & 0.82 & 19.3 & 19.8 & 19.8 & 19.7 & 19.6 & 0.3 \\
\hline \multirow{3}{*}{$\begin{array}{l}\text { Shallow glide } \\
\text { - exposed, } \\
20\end{array}$} & WWF1 & Trans 1 & 0.18 & 0.61 & 1.22 & 1.68 & 1.83 & 1.83 & 16.3 & 16.6 & 16.6 & 16.6 & 16.7 & 0.4 \\
\hline & WWF1 & Trans2 & 0.76 & 1.22 & 0.91 & 0.46 & 0.15 & 1.22 & 16.4 & 16.7 & 16.7 & 16.7 & 16.4 & 0 \\
\hline & WWF1 & Trans3 & 0.18 & 0.35 & 0.55 & 0.67 & 0.44 & 0.67 & 16.2 & 16.6 & 16.6 & 16.5 & 16.4 & 0.2 \\
\hline \multirow{4}{*}{$\begin{array}{l}\text { Large in- } \\
\text { channel } \\
\text { wood } \\
\text { corridor, } 15\end{array}$} & CWF9 & Trans 1 & 2.13 & 1.37 & 1.22 & 1.07 & 1.83 & 2.13 & 17 & 17 & 17 & 17 & 17 & 0 \\
\hline & CWF9 & Trans2 & 0.30 & 0.61 & 0.91 & 1.52 & 1.83 & 1.83 & 17 & 17 & 17 & 17 & 17 & 0 \\
\hline & CWF9 & Trans3 & 0.61 & 1.22 & 1.22 & 1.83 & 2.59 & 2.59 & 17.1 & 17.1 & 17.1 & 17 & 17.1 & 0 \\
\hline & CWF9 & Trans4 & 0.27 & 0.30 & 0.24 & 0.40 & 0.58 & 0.58 & 17.2 & 17.2 & 17.3 & 17.2 & 17.2 & 0 \\
\hline \multirow{3}{*}{$\begin{array}{l}\text { Extended pool } \\
\text { - shaded, } \\
14.5\end{array}$} & CWF10 & Trans1 & 0.61 & 0.46 & 0.30 & 0.91 & 0.76 & 0.91 & 17.3 & 17.3 & 17.5 & 18 & 18 & 0.7 \\
\hline & CWF10 & Trans2 & 0.61 & 0.91 & 0.91 & 0.46 & 0.61 & 0.91 & 17 & 17 & 17.2 & 17.3 & 17.9 & 0.9 \\
\hline & CWF10 & Trans3 & 0.61 & 1.37 & 1.52 & 0.30 & 0.15 & 1.52 & 17.2 & 17.3 & 17.6 & 18 & 18.1 & 0.9 \\
\hline
\end{tabular}

${ }^{1}$ Cross section locations where the current was too swift to measure depth and temperature. 
Overall, the data suggest that CWFs in the lower Quinault River are most often associated with shade. The occurrence of cold-water tributaries or cooler side channels along the lower Quinault River appears to be limited and their contribution of cold water to the main channel also appears to be limited to the immediate confluence area. Consistent, cooler temperatures at CWF 9, which are associated with the large, in-channel wood may be a combined result of shading and the presence of deeper water, which presumably is facilitated by the presence of the large wood jams.

The study did not include data collection on availability of fine-scale (for example, less than 10 m) cold or cooler water refugia associated with individual local-scale channel features such as side pool density or density of individual pieces of large wood not associated with jams. However, both side pools and large wood along channel margins appeared to be more frequent in the downstream direction based on field observations. It is likely that cooler water temperatures relative to the mainstem would be associated with these fine-scale habitat features (Ebersole and others, 2003).

\section{Summary}

Stream water temperatures collected during the partial summer of 2016 and extending through summer 2017 in the lower Quinault River indicate that summertime baseflow temperatures exceeded salmon species threshold values of 16 and $17.5^{\circ} \mathrm{C}$ for several weeks to a couple of months beginning in late June and extending through September. Measured water temperatures were higher than modelpredicted temperatures for the period, 1993-2011 (Isaak and others, 2011). Temperatures generally decreased in the downstream direction during the summer, but increased in the downstream direction during the rest of the year, suggesting a moderating groundwater influence. Near-streambed temperature ranged from 17.9 to $21.7^{\circ} \mathrm{C}$ during the longitudinal temperature survey along the lower Quinault River in August 2016. The resulting longitudinal profile did not indicate cold-water refugia that was more than $3{ }^{\circ} \mathrm{C}$ cooler than ambient stream water. Instead, CWFs $\left(0.1^{\circ} \mathrm{C}\right.$ cooler $)$ appear to exist at spatial scales of 100-800 m suggesting diffuse groundwater influences or the influence of shading from solar radiation by steep river banks or riparian vegetation. In addition, field observations suggest that finer-scale (for example, less than $10 \mathrm{~m}$ ) features associated with individual side pools or large, in-channel wood, increase in frequency in the downstream direction along lower Quinault River, which may serve as cool or cold-water pockets or patches, although this study did not quantify the density or water temperatures associated with these fine-scale features.

\section{Acknowledgments}

The authors would like to thank Christa Anhold for assistance in collecting water temperature data and Alison Tecca and Raegan Huffman for assistance in water temperature data review and approval. 


\section{References Cited}

Ebersole, J.L., Liss, W.J., and Frissell, C.A., 2003, Cold water patches in warm streamsPhysicochemical characteristics and the influence of shading: JAWRA Journal of the American Water Resources Association, v. 39, no. 2, p. 355-368, https://doi.org/10.1111/j.17521688.2003.tb04390.x.

Fullerton, A.H., Lawler, J.J., Lee, S.-Y., and Torgersen, C.E., 2017, Incorporating spatial heterogeneity in temperature into climate vulnerability assessments for coastal Pacific streams: Final Report to the North Pacific Landscape Conservation Cooperative, September 30, 2017, accessed December 1, 2017, at https://www.sciencebase.gov/catalog/item/54b345aee4b07ebaa4aaca08.

Isaak, D.J., Wenger, S.J., Peterson, E.E., Ver Hoef, J.M., Hostetler, S., Luce, C.H., Dunham, J.B., Kershner, J., Roper, B.B., Nagel, D., and Horan, D., 2011, NorWeST-An interagency stream temperature database and model for the Northwest United States: U.S. Fish and Wildlife Service, Great Northern Landscape Conservation Cooperative Grant. Project website, accessed December 15, 2017, https://www.fs.fed.us/rm/boise/AWAE/projects/NorWeST.html.

Jaeger, K.L, Curran, C.A., and Opatz, C.C., 2018, Water temperature and stream depth data for the lower Quinault River during summer baseflow, Washington, August 2016 and 2017: U.S.

Geological Survey data release, https://doi.org/10.5066/F7C53J2D.

Mantua, N., Tohver, I., and Hamlet, A., 2010, Climate change impacts on streamflow extremes and summertime stream temperature and their possible consequences for freshwater salmon habitat in Washington State: Climatic Change, v. 102, no. 1-2, p. 187-223, https://doi.org/10.1007/s10584010-9845-2.

Mellina, E., Moore, R.D., Hinch, S.G., Macdonald, J.S., and Pearson, G., 2002, Stream temperature responses to clearcut logging in British Columbia - The moderating influences of groundwater and headwater lakes: Canadian Journal of Fisheries and Aquatic Sciences, v. 59, no. 12, p. 1886-1900.

Mote, P.W., and Salathé, E.P., Jr., 2010, Future climate in the Pacific Northwest: Climatic Change, v. 102, no. 1-2, p. 29-50, https://doi.org/10.1007/s10584-010-9848-z.

O’Connor, J.E., Jones, M.A., and Haluska, T.L., 2003, Flood plain and channel dynamics of the Quinault and Queets Rivers, Washington, USA: Geomorphology, v. 51, nos. 1-3, p. 31-59, https://doi.org/10.1016/S0169-555X(02)00324-0.

Olden, J.D., and Naiman, R.J., 2010, Incorporating thermal regimes into environmental flows assessments-Modifying dam operations to restore freshwater ecosystem integrity: Freshwater Biology, v. 55, no. 1, p. 86-107, https://doi.org/10.1111/j.1365-2427.2009.02179.x.

Richter, A., and Kolmes, S.A., 2005, Maximum temperature limits for Chinook, Coho, and Chum salmon, and steelhead trout in the Pacific Northwest: Reviews in Fisheries Science, v. 13, no. 1, p. 23-49, https://doi.org/10.1080/10641260590885861.

U.S. Geological Survey, 2018, USGS surface-water data for Washington: U.S. Geological Survey National Water Information System, accessed March 15, 2018, at https://waterdata.usgs.gov/wa/nwis/sw.

Vaccaro, J., and Maloy, K., 2006, A thermal profile method to identify potential ground-water discharge areas and preferred salmonid habitats for long river reaches: U.S. Geological Survey Scientific Investigations Report 2006-5136, 16 p.

Wagner, R.J., Boulger, R.W., Jr., Oblinger, C.J., and Smith, B.A., 2006, Guidelines and standard procedures for continuous water-quality monitors: station operation, record computation, and data reporting: U.S. Geological Survey Techniques and Methods 1-D3, 51 p.

Washington State Department of Ecology, 2016, WAC 173-201A-Water quality standards for the surface waters of the state of Washington: Olympia, Washington, Washington State Department of Ecology, Publication summary, accessed on December 1, 2017, at https://fortress.wa.gov/ecy/publications/SummaryPages/0610091.html. 
Publishing support provided by the U.S. Geological Survey

Science Publishing Network, Tacoma Publishing Service Center

For more information concerning the research in this report, contact the Director, Washington Water Science Center

U.S. Geological Survey

934 Broadway, Suite 300

Tacoma, Washington 98402

https://wa.water.usgs.gov 
